\title{
Ensimmäisten suomenkielisten murretutkimusten metakieli
}

\author{
Aila Mielikëinen
}

\section{Johdanto}

Suomen murteisiin kohdistuvan systemaattisen kielentutkimuksen on katsottu alkaneen 1870-luvulla. Jo tätä ennen valmistui kaksi ruotsinkielistä tutkimusta lounaisten siirtymämurteiden (Avellan n. 1846-1854; ks. Rapola 1961: 28) ja Satakunnan alueelta (Järvinen 1854) sekä Antero Vareliuksen ruotsinkielinen selvitys suomen itä- ja länsimurteiden rajasta (Warelius 1848). Avellanin tutkimus julkaistiin vasta 1900-luvun alussa Heikki Ojansuun suomennoksena. Ensimmäinen suomenkielinen murretutkimus oli J. A. Hahnssonin useampiosainen muoto-opillinen selvitys eräistä lounaismurteista (Hahnsson 1866-1872). August Ahlqvistin tultua suomen kielen professoriksi ja Suomalaisen Kirjallisuuden Seuran (SKS) sihteeriksi 1863 virisi murteiden keruu ja tutkimus hänen ohjauksessaan uudella tavalla. SKS jakoi keruumatkoja varten stipendejä ja julkaisi sittemmin valmistuneet tutkimukset Suomi-sarjassa. (Niinivaara 1931: 10-11; Rapola 1961: 23-28; Korhonen 1986: 94-95.) Murteiden keruu ja tutkimus kuului myös vuonna 1876 perustetun Kotikielen Seuran ohjelmaan. Seurassa toimi eräänlainen tutkijaseminaari, jossa tarkastettiin murteiden esittelyjä 1880-189o-luvulla (Paunonen 1976: 380-381).

Ensimmäisten vuosikymmenien murretutkimukset noudattelivat tuolloin vallinneen komparatiivisen eli vertailevan kielentutkimuksen periaatteita. Käsittelytapa oli deskriptiivinen, ja vertailukohteena pidettiin kielioppien kuvaamaa kirjakieltä. Kielioppien tapaan tutkimukset sisälsivät sekä äänne- että muoto-opin, ja joissakin oli lisäksi lauseoppia ja kielennäytteitä. Lauseopista ilmestyi 1800-luvun loppupuolella myös muutama erillistutkimus. 1870-luvulla tapahtui Keski-Euroopassa uuden nuorgrammaattisen koulukunnan vuoksi tutkimusparadigman muutos ja huomion kohteeksi nousi murteiden äännehistoriallinen kehitys. ${ }^{1}$ Suomalaiseen tutkimukseen uudet menetelmät pääsivät vaikuttamaan 1880-luvun loppupuolelta lähtien, ennen kaik-

1. Vuotta 1876 on luonnehdittu eräänlaiseksi murteentutkimuksen merkkivuodeksi: Tuolloin nuorgrammaatikot julkistivat periaatteensa kielen muuttumisesta. Samana vuonna ilmestyivät Eduard Sieversin Grundzüge der Lautphysiologie (seuraavissa painoksissa Grundzüge der Phonetik) ja Jost Wintelerin uusia menetelmiä noudatteleva tutkimus eräästä Sveitsin kantonin murteesta. Vuoteen 1876 osuu neljäskin merkittävä tapahtuma, murremaantieteen synty, sillä silloin aloitti saksalainen Georg Wenker keruutyönsä murrekartastoa varten. (Petyt 1980: 39-40 ja siinä mainitut lähteet.) 
kea E. N. Setälän Yhteissuomalaisen äännehistorian (1890-1891) kautta. (Rapola 1961: 28-29; Itkonen 1966: 33-36.) Selvä metodien ja esitystavan muutos ilmenee kuitenkin vasta 1890 -luvun jälkipuoliskon murretutkimuksissa. Sitä ennen ehti ilmestyä kolmattakymmentä suomenkielistä murretutkimusta ja murre-esittelyn sisältävää pitäjänkertomusta (ks. Rapola 1961: 146-147).

Murteentutkimuksen alku sijoittuu kirjakielen historiassa varhaisnykysuomen kaudelle (n. 1810-1880), jolloin suomen kielestä kehitettiin eri aloilla käytettäväksi sopivaa sivistyskieltä. Kyse oli ennen kaikkea suomen kielen käyttöalan laajentamisesta (Huumo 2005: 57), ja tavoite edellytti kirjakielen normittamista ja sanaston tietoista kehittelyä. Periaatteena oli omakielinen sanasto, ja uudissanoja saatiin muun muassa tutuista sanoista johtamalla ja yhdistämällä, antamalla tutuille sanoille uusia merkityksiä ja käyttötapoja sekä muista kielistä kääntämällä. Tieteen kieleksi suomi pääsi vasta 180o-luvun lopussa ja 1900-luvun alussa, mutta sanaston kehittäjät loivat jo aikaisemmin eri tieteenaloille omakielistä termistöä (ks. Pitkänen 2008: 14-17). 180o-luvun kirjasuomen tutkimuksessa on tällä vuosituhannella selvitelty Lönnrotin luomaa kasvitieteen sanastoa (Pitkänen 2008) ja maantieteen oppikirjoissa käytettyä erikoissanastoa (Laine 2007). Kielentutkimuksessa uudissanastoa tarvittiin varsinkin kielioppeihin; ensimmäisen suomenkielisen kieliopin julkaisi H. K. Koranteri (Corander) 1845, toisen G. E. Eurén 1852 (Häkkinen 2000: 178).

Murteentutkijoiden oli luotava oma erikoiskielensä ja termistönsä, sillä kieliopit keskittyivät muoto-oppiin eikä niiden sanasto riittänyt murteille tyypillisten äännevaihtelujen käsittelyyn. Aiemmissa kieliopeissa murteita olivat käsitelleet muun muassa Bartholdius Vhael (1733), Reinhold von Becker (1824) ja Gustaf Renvall (1840); näiden kielioppien kieli oli kuitenkin latina tai ruotsi. Murteista oli ilmestynyt myös joitakin artikkeleita, mutta nekin olivat ruotsin- tai latinankielisiä (esim. Erik Lencqvist 1777; H. G. Porthan 1801). (Ks. Rapola 1961: 23-26.) Murteiden taistelun virittämät keskustelut käytiin 1800-luvun alkupuolella enimmäkseen ruotsiksi, ja suomenkielisistä kirjoituksistakin on huomattava, että niissä käsiteltiin murteita vain suhteessa kirjakieleen ja sen kehittämiseen. Kielentutkimuksesta oli kaikkiaan kirjoitettu suomeksi vähän. Suomi-sarjan pääkielenä oli vuodesta 1841 lähtien ruotsi, ja suomen kieleen siirryttiin kokonaan vasta 1860-luvun lopussa (ks. Huumo 2005: 68, 208). SKS:n pöytäkirjoista näkyy, että ainakin yksi alkuvaiheen murretutkimus (Almberg 1870) oli annettu tekijälle suomennettavaksi ennen sen painamista (SKS 1867-68: 436). Suomen kieli pääsikin kansallisissa tieteissä käyttöön muita aloja aikaisemmin. Yliopistossa ensimmäiset suomenkieliset maisterinväitöskirjat hyväksyttiin 1830-luvulla, ja luentokielenä suomea sai virallisesti käyttää 1860-luvulta lähtien. (Häkkinen 2008: 81-82; ks. myös 1994: 69-72.)

\section{Tutkimusaineisto ja tavoitteet}

Tässä artikkelissa tarkastelen suomalaisen murteentutkimuksen metakieltä ennen nuorgrammaattista suuntausta. ${ }^{2}$ Termillä metakieli tarkoitetaan kielitieteessä kieltä

2. Kiitän Virittäjän anonyymeja arvioijia lausunnoista ja huomautuksista, jotka auttoivat tarkista- 
tai kielimuotoa, jota käytetään puhuttaessa tutkimuskohteena olevasta kielestä (Tieteen termipankki: 31.10.2016, Kielitiede:metakieli). Päätavoitteeni on selvittää, millaista on ollut 180o-luvun äänneopillisissa tutkimuksissa käytetty tieteellinen suomen kieli, kun siihen ei ole vielä ollut valmista suomenkielistä sanastoa eikä muitakaan malleja. Rajaan analyysini murrepiirteiden kuvauksiin, koska niissä käytetyn metakielen voi olettaa valaisevan laajemminkin tutkijoiden käsityksiä murreilmiöistä ja niiden taustoista. Pohdin artikkelissani seuraavia kysymyksiä: Millaisin ilmauksin kielenpiirteitä ja murrevariantteja nimetään, määritellään ja kuvaillaan? Miten tämä kielenkäyttö eroaa myöhempiin äännehistoriallisiin tutkimuksiin vakiintuneesta kielestä ja siihen kuuluvista keskeisistä termeistä? Voiko kielenkäytön perusteella tehdä päätelmiä deskriptiivisen tutkimuksen suhteesta historioivaan tutkimukseen? Tarkastelen metakieltä myös 180o-luvun kirjakielen kehityksen taustaa vasten: onko sanastossa esimerkkejä murresanoista, tietoisista sepitteistä tai vierassanojen ja omaperäisten sanojen kilpailusta? Perusteellisempi selvitys sanojen alkuperästä ja taustoista olisi kuitenkin eri tutkimuksen aihe.

Aineistonani ovat vuosina 1866-1893 ilmestyneet suomenkieliset murretutkimukset, jotka käsittelevät äänne- ja muoto-oppia mutta eivät seuraile vielä Setälän Yhteissuomalaisen äännehistorian mallia. Lisäksi olen ottanut mukaan kolme pitäjänkertomusta, joista vanhimmat ovat jo 1850-luvulta (Koskinen 1852 [1851]; Warelius 1855 [1853]; Aspelin 1870). Pitäjänkertomukset esittelevät muun muassa paikkakunnan historiaa, luontoa ja taloutta, ja niissä on usein suppea murrekatsaus, joka ei rinnastu varsinaisiin tutkimuksiin mutta sisältää näihin rinnastettavaa metakieltä. Julkaisuja on yhteensä 23, ja yhtä lukuun ottamatta ne kuuluvat Rapolan laatimaan luetteloon (1961: 146-147). Suurin osa niistä on julkaistu Suomi-sarjassa ${ }^{3}$. (Ks. Aineistolähteet.) Tarkastelemani ajanjakson päätösvaihe ei osu täsmällisesti Setälän äännehistorian ilmestymiseen, eikä metodinen rajakaan ole jyrkkä. Nuorgrammaattisia vaikutteita alkoi tulla esiin jo 188o-luvun lopussa, ja myös foneettisen tutkimuksen vaikutus vahvistui samanaikaisesti. Taitekohtaa edustavat aineistossani vuosien 1888-1893 tutkimukset, mutta uudet vaikutteet näkyvät tuona aikana selvästi vain kolmessa tutkimuksessa. Näistä kolmesta olen ottanut mukaan Knut Cannelinin (1889 [1888]) ja Otto Hyyryläisen (1893) tutkimukset, koska niiden sisältö ja dispositio noudattavat aiempia malleja. Molempiin kuuluu vielä laajahko muoto-opin osuus, jota äännehistoriallisissa tutkimuksissa ei enää ole. Yrjö Wichmannin tutkimuksen (1893) olen jättänyt pois siksi, että sen analyysin kohteena ja jäsentelyperusteena on murteen fonetiikka.

Aineistoni tutkimuksissa murteita vertaillaan kirjakieleen sellaisena kuin se esitetään kieliopeissa. Vertailukohteena on useimmin mainittu Eurénin Suomalaista kielioppia Suomalaisille (1852), ja 1880-luvulla sen rinnalle tai tilalle tulevat August Ahlqvistin (1877) ja Arvid Genetzin (1881) kieliopit. Kielioppien tapaan murretutkimuksissa on äänne- ja muoto-oppi, toisinaan myös lauseoppi, ja joskus näiden

maan joitakin yksityiskohtia ja paneutumaan perusteellisemmin tutkimuksen taustoitukseen.

3. Käytän Suomi-sarjan julkaisuista lähdeviitteissä yhtenäisyyden vuoksi kyseisen osan julkaisuvuotta, vaikka jotkut tutkimukset ovat ilmestyneet jo vuotta aikaisemmin (vrt. Rapola 1961: 146-147). Lähdeluettelossa mainitsen molemmat vuodet. 
yhteisenä yläotsikkona on Kielioppi (esim. Westerlund 1883; Toivonen 1889; Lindfors 1893). Tekijöiden vaihtelevat taustat ${ }^{4}$ ovat vaikuttaneet jossain määrin paitsi tutkimusten laajuuteen, sisältöön ja käsittelytapaan myös lähteiden käyttöön. Suppeimmissa julkaisuissa ei mainita edes kielioppia, kun taas kielentutkijoilla on alusta lähtien muita enemmän kielitieteellisiä lähteitä. Julkaisujen karttuessa viitataan myös aiempiin murretutkimuksiin.

Olen poiminut kaikkien tutkimusten äänneopillisesta osuudesta systemaattisesti murrepiirteiden käsittelyyn liittyvän metakielisen sanaston, sanaluokasta riippumatta (esim. schwa, piteneminen, vaihtua). Tutkimuskohteen vuoksi sanat ovat enimmäkseen substantiiveja ja verbejä. Joissakin tapauksissa olen ottanut esimerkkejä myös muoto-opin puolelta. Metakielen merkitystä kielitieteessä ja suomalaisessa murteentutkimuksessa on pohtinut Tapani Kelomäki (2009). Hän on kuitenkin keskittynyt äännehistoriallisen tutkimuksen yleiskäsitteiden ja metodisten termien käyttöön (esim. äännelaki, äänteenmuutos), ei varsinaisiin murrepiirteisiin. Viime vuosikymmeninä metakieli-termi on tullut tutuksi kansanlingvistisessä tutkimuksessa, jossa on tarkasteltu ei-kielitieteilijöiden eli "maallikoiden" käsityksiä ja havaintoja kielestä ja murteista. Suomalaisessa kansanlingvistiikassa on analysoitu 200o-luvulla lähemmin Dennis Prestonin nimeämän ja määrittelemän metakielen sisältöä ja ryhmitelty siihen kuuluvia ilmauksia. Ei-kielitieteilijöiden kielenkäytöstä on erotettu muun muassa kielimuotojen, murteiden ja murrepiirteiden terminomaisia nimityksiä mutta myös muita ilmauksia, joilla kieltä ja sen ilmiöitä on kuvattu. ${ }^{5}$ (Mielikäinen 2005; Mielikäinen \& Palander 2014: 26-29.)

Koska murteentutkimuksen metakielestä ei ole tehty muita selvityksiä, olen hyödyntänyt aineiston poiminnassa ja analyysissa osittain kansanlingvistisen tutkimuksen määrittelyjä. Ensimmäisten murteentutkijoiden ja oman aikamme eikielitieteilijöiden välillä on monessa suhteessa suuri ero, mutta yhteistä heille on se, että kummallakaan ryhmällä ei ole ollut valmiita malleja sille, miten puhua murteista. Tutkimuskohteeni on suppeampi kuin kansanlingvistiikassa, sillä keskityn vain murrepiirteiden nimeämiseen ja kuvailuun; muita kansanlingvistiikassa kerättyjä ilmaustyyppejä kielitieteellisissä teksteissä on vähän tai ei lainkaan. Analyysin ulkopuolelle jätän myös varsinaiset kielioppitermit, kuten taivutuskategorioiden nimitykset, sekä äänteisiin liittyvät foneettiset termit, elleivät ne tule esiin murrepiirteiden käsittelyssä. Jälkimmäinen rajaus vähentää analysoimassani sanastossa adjektiivien osuutta (esim. aukenevainen, kokopitkä). Suhteessa erikoisalojen termistöön metakieli on laajempi käsite, eikä poimimani sanasto vastaa kaikilta osin tyypillistä erikoissanastoa. Termit ovat oppi- tai ammattisanoja, joille on kehittynyt omalla erikoisalallaan tarkasti määritelty, kontekstista riippumaton merkitys. Ensim-

4. Tutkimusten tekijöissä on kielen ja historian tutkijoita, opettajia ja lehtimiehiä sekä muidenkin alojen edustajia, ja on huomattava, että osa tutkimuksista on heidän nuoruudentöitään. Kahdella tutkijalla on Suomi-sarjassa kaksi julkaisua (Aminoff 1871, 1876; Salonius 1872, 1881).

5. Ei-kielitieteilijöiden metakieleen on luettu Mielikäisen ja Palanderin mukaan (2014: 27-28) murteiden ja muiden kielimuotojen nimitykset (Keuruun murre, nuorisokieli), murrepiirteisiin viittaavat nimitykset ja määrittelyt (venytys, katkaista), puhetavan, murteiden, murrepiirteiden ja ääntämyksen kuvailut (pajatus, vahva, suhista), subjektiivista asennoitumista ilmaisevat sanat (ihailla, ärsyttävä) sekä murteiden ja piirteiden havainnointiin liittyvät ilmaukset (kuulostaa, pistää korvaan). 
mäisten murretutkimusten metakieli ei ole vielä ehtinyt vakiintua, ja termiytymisprosessin selvittäminen vaatisi aineistoa pitemmältä ajanjaksolta (termiytymisestä ks. esim. Haarala 1981: 15-16). En tarkastelekaan sanastoa varsinaisesti termiyden näkökulmasta, vaan pyrin analysoimaan sitä suhteessa äännehistorioiden termistöön (luku 3), 180o-luvun kirjasuomeen (luku 4) ja tutkimusparadigmojen eroihin (luku 5). Sanaesimerkkien lisäksi esitän aineistosta lausesitaatteja, jotka valaisevat sanojen käyttöä aidossa kontekstissa, synonyymisten ilmausten vaihtelua ja joskus myös poikkeuksellisia sananvalintoja.

\section{Murrepiirteisiin liittyvä metakieli}

Tarkastelemani tutkimukset jakautuvat alueellisesti kaikille nykyryhmityksen mukaisille päämurrealueille. Eniten niitä on savolais- ja hämäläismurteista, vähiten keski- ja pohjoispohjalaisista murteista. Alueellisen jakauman vuoksi aineistossa tulevat käsitellyiksi useimmat keskeiset murrepiirteet. Kaikissa tutkimuksissa esitellään kielioppien mukaisesti klusiilien astevaihtelu, ja myös laajalle levinneet piirteet, kuten yleisgeminaatio, svaavokaali, liudennus ja loppuheitto, toistuvat useissa kuvauksissa. Näissä ilmiöissä tutkijoiden käyttämä metakieli on yhtenäisintä, vaikkakaan ei vaihtelutonta. Tyypillistä tälle metakielelle on se, että samaa ilmiötä voidaan nimetä ja kuvata monella tavalla ja että samalla ilmauksella voidaan viitata useaan piirteeseen. Perusnimityksissä on sekä nykytutkimuksesta tuttuja että käytöstä poistuneita termejä. Murrepiirteiden käsittelyssä kuvataan myös vähittäisissä muutoksissa ilmeneviä foneettisia eroja, kuten kestoa tai vokaalien ääntämystä. Seuraavassa lähden liikkeelle piirteiden nimityksistä (luku 3.1) ja tarkastelen sen jälkeen ääntämyksen kuvailuja (luku 3.2).

\subsection{Murrepiirteiden nimeäminen}

Kaikissa tutkimuksissa käsiteltyihin piirteisiin kuuluu klusiilien astevaihtelu. t:n heikkoasteiset murrevastineet poikkeavat kirjakielen edustuksesta, ja $k: n$ astevaihtelussakin on murre-eroja. Termi astevaihtelu on vielä tuntematon, mutta kieliopeista on saatu paitsi selkeä malli ilmiön käsittelyyn myös yhdenmukainen pehmeäkantainen sanasto: (konsonanttien) pehmeneminen, pehmentäminen, pehmennys, pehmetä, pehmentyä (esim. 1-3). Vanhimmissa tutkimuksissa käytetään johdoksia pehmitys ja pehmittää. Sanat pehmeä ja pehmeneminen esiintyvät myös Eurénin kieliopissa (1852: 21-24), ja sananvalintojen taustalla on soinnittomien klusiilien nimittäminen koviksi konsonanteiksi.

(1) Ylimalkaan tapahtuu pehmennys aivan samoissa suhteissa kuin kk:ssä [kirjakielessä]. (Lönnbohm 1879: 21)

(2) T tietysti ei koskaan pehmene $d$ :ksi kun $d$ :tä ei murteessa ole, vaan katoo peräti. (Salonius 1881: 263) 
(3) K:ta pehmittäissä $h: n, i: n, l: n$ tai $r: n$ jälessä, on tapa venyttää seuraavaista äänikettä [nahiaasta, pel’oolla] ${ }^{6}--$. (Koskinen 1852: 50)

Itä- ja länsimurteissa laajalle levinneestä yleisgeminaatiosta ja lounaismurteiden erikoisgeminaatiosta käytetään ilmauksia kertominen, kertoa, (joskus) kertoutua tai piteneminen, pitennys, pidetä, pitentyä, joskus myös muuttua pitkäksi, lausua pitkänä (esim. 4-6). Kertoa-verbin käyttö perustuu sanan aiempaan, murteissakin ensisijaiseen merkitykseen 'kerrata, toistaa' (VKS s. v. kertoa; SMS s. v. kertoa). 188o-luvulla ilmaantuu kuvauksiin kaksi-numeraaliin perustuvia termejä: kaksistua, kaksinkertainen, kaksinkertaisuus (esim. 7).

(4) Tämä sääntö, jonka jälkeen Turun murteessa kerakkeita kerrotaan, on pääasiallisesti eroava siitä [yleisgeminaation] säännöstä, minkä jälkeen Tammelassa, Loimaalla - -, eli pitäjissä Loimajoen ja Kokemäen joen ympäristöllä, kertominen tapahtuu. (Salonius 1872: 92)

(5) Kaikki yksinäiset konsonantit kertoutuvat sanan sisässä tavuun alussa, kun edellä käy lyhyt korollinen vokaali ja jäljessä on pitkä vokaali taikka diftongi [yleisgeminaatio] - -. (Lönnbohm 1879: 24)

(6) Konsonanttien pitentymisessä Pohjois-Savon murteessa huomaamme [yleisgeminaation] yleiseksi säännöksi seuraavan: - -. (Brax 1890: 233)

(7) Niinikään kaksistuu $s$ kaikissa $s e$-vartaloisissa sanoissa [ihmissi] - -. (Toivonen 1889: 134)

Ilmaukset pehmeneminen ja kertominen ovat vanhoissa murretutkimuksissa yksiselitteisiä, terminomaisia nimityksiä astevaihtelulle ja geminoitumiselle. Sanoja saatetaan silti käyttää muidenkin ilmiöiden kuvauksissa. Pehmenemiseksi nimitetään myös tavunloppuisten klusiilien (kakla, kakra) vokaaliutumista (Könönen 1888: 14), ja kertoa-verbi sopii merkityksensä puolesta svaan laadun määrittelyyn: svaavokaalina kerrotaan ensimmäisen tavun vokaali (esim. Aminoff 1871: 239; Chydenius 1886: 101).

Nykytutkimuksesta tuttuja termejä ovat svaavokaalin nimitykset schwa (shvaa) ja välivokaali. Näiden lisäksi svaata nimitetään usein puolivokaaliksi, ja funktionsa vuoksi sitä luonnehditaan vokaaliseksi väliäänteeksi tai joskus apuääntiöksi: "Samoin kuin Itä-Suomesta, löydämme tästäkin [Isojoen] murteesta 'schva' äänen eli puolivokalin” (Almberg 1870: 111). Nimityksellä puolivokaali on ilmeisesti viitattu svaan kestoon tai siihen, ettei svaa ole saanut sanassa täyden vokaalin asemaa. Vielä 190o-luvun alussa on svaata nimitetty puolivokaaliksi ja jopa siirtymä-äänteeksi (Tarkiainen 1913: 94), vaikka äänteiden foneettisessa ryhmittelyssä puolivokaaleiksi on jo tuolloin määritelty konsonantit $j$ ja $v$. Äännehistorioihin on vakiintunut svaa tai svaavokaali (alku-

6. Sitaateissa hakasulkeisiin merkityt murre-esimerkit ovat aina peräisin tutkimuksen tekijän tekstistä. Myös sitaattien kursivoinnit ja harvennukset ovat alkuperäisen lähteen mukaisia. 
perästä tarkemmin luvussa 4.1), mutta vanhaa yleisnimitystä välivokaali on alettu käyttää viime vuosikymmeninä uudestaan (ks. Mielikäinen \& Palander 2014: 129).

Toinen uusimpiin äännehistorioihin saakka säilynyt termi on itämurteiden tutkimuksissa esiintyvä liudennus. Sen synonyymina on vanhoissa murretutkimuksissa usein vierassana muljeeraus (muljeerata, muljeerautua, esim. 8; ks. lukua 4.1). Liudennusta vastaava verbi on kuitenkin liutua (liutuminen), vain harvoin liudentua (esim. 9-10). Ä̈nteellisesti läheisiä liutua-pesyeelle ovat Jänneksen (1890) käyttämät vastineet hiuvennus, hiueta : hiukenee ja hiuventaa (esim. 11). Liudennuksen yhteydessä puhutaan myös $i$ :n ja konsonantin sulamisesta tai sulautumisesta (esim. 9-10). Muodot liutua ja hiueta ovat peräisin murteista, ja eri merkitysten joukossa niillä on yhteisenä merkityksenä 'sulaa, pehmetä' (SMS 2016 s. v. liutua; SMS s. v. hiueta).

(8) Monikon merkki muljeeraa monitavuisissa sanoissa instruktiivin päätteen [jalon'] - -. Superlatiivin i:n vaikutuksesta on syntynyt sellainenkin muljeeraus kuin van'hin. (Könönen 1888: 11)

(9) Konsonanttien liudennus. Tällä nimellä kutsun sitä ilmiötä, että jotkut kieliäänteet voivat sulaa, ikään kuin liutua seuraavan $i$ :n kanssa yhdeksi ääneksi. - - Toisinaan tapasin liudennuksen sellaisissakin sanoissa, joissa $i$ on kadonnut liudentuvan konsonantin edeltä [hevońe] - -. (Lönnbohm 1879: 21)

(10) [Sananloppuinen $i$ on] sulautunut edellä olevaan konsonanttiin, niin ettei tätä enää äännetä semmoisenaan, vaan liutuneena - -. (Brax 1890: 234)

(11) Dentaali-konsonanttien hiuvennus seuraavan $i$ :n tai j:n vaikutuksesta on jotenkin yleinen - -. (Jännes 1890: 338)

Lähes kaikissa tutkimuksissa käsitellään loppuheittoa, koska useimmissa suomen murteissa esiintyy jotain sen tyyppiä. Metakielen näkökulmasta loppuheitto jää kuitenkin alisteiseksi äänteiden kadolle, eli se on tämän alakäsite. Äänteiden kadosta käytetään samanlaisia ilmauksia siitä riippumatta, onko kyseessä vokaali vai konsonantti ja onko äänne kadonnut sanan alusta, sisältä vai lopusta. Sanasto on tästä syystä kirjavampi ja tyylillisesti vaihtelevampi kuin edellä esitellyissä piirteissä. Termimäisimpiä ilmauksia ovat poisheitto, heitto, heittyminen ja elisio(ni) tai vastaavat verbit heittää (pois), heittyä, jäädä pois ja elideerautua (esim. 12-16). Lisäksi on käytössä useita muita erityylisiä ilmauksia, esimerkiksi kadota, kulua ja haihtua.

(12) Tavallisin on loppuvokaalin heitto paikallisuuden sijoista, kuin joku muoto on tahi ei verbeistä seuraa. (Chydenius 1886: 104)

7. Hakulinen (1979: 465) mainitsee liudentua-verbin 1880-luvun uudissanavastineena muljeerautuaverbille, mutta verbiä on käytetty jo 1870-luvulla (Lönnbohm 1879). Liudentua on yleistynyt viime vuosikymmeninä ei-tieteelliseen kielenkäyttöön merkityksessä 'hälventyä, hämärtyä; lieventyä, tasoittua, vesittyä' (ks. Pulkkinen 1996). Pesyeeseen kuuluvien sanojen uudet merkitykset ovat päässeet kielitieteellisen merkityksen rinnalle vasta Kielitoimiston sanakirjan verkkoversiossa (KS). 
(13) A ja ä heittyvät aina inessiivin, elatiivin, adessiivin ja ablatiivin päätteistä - -. (Lindfors 1893: 9)

(14) J heittyy aina sanan alusta ä̈̈:stä syntyneen ie:n edestä, esim. ie (= jää) - -. (Lindfors 1893: 15)

(15) Sanan lopusta heitetään $i$ pois useammin nominien nominativissa, harvemmin verbien impf:ssä - - . (Hannikainen 1886: 112)

(16) Partikkelista kanssa - - elideerautuu useimmiten loppu-a - -. (Grotenfelt 1878: 313)

Nykyiseen dialektologiaan vanhasta termistöstä ovat säilyneet elisio ja heittyä, mutta vain vokaalien kadosta käytettyinä; lisäksi elisio on supistunut merkitykseltään lausefoneettisen kadon eli vokaalialkuisten sanojen edellä tapahtuneen loppuheiton nimitykseksi (siin oli, ns. sandhiloppuheitto; NS s. v. elisio). Muut yksinäisvokaalin katotapaukset määritellään nykyään heitto-loppuisilla yhdyssanoilla sisäheitoksi 'synkopee' ja loppuheitoksi 'apokopee. Konsonanteista käytetään sen sijaan vain kato-pesyeen ilmauksia: vokaalienvälisen h:n kato, loppu-n on kadonnut. Vaikka sisä- ja loppuheitto puuttuvat vanhoista tutkimuksista, takaheitosta eli metateesista (hevosein, maalima) on pari mainintaa (Lönnbohm 1879: 27-28; taaheitto, Westerlund 1883: 192).

Kieliopeista on murrepiirteiden käsittelyyn saatu useita piirteitä yhteen nivova termi supistuminen (supistuma, supistaa, supistua) eli kontraktio(ni). Suomen kielen muoto-opin taivutuskaavoissa sitä on tarvittu nominien ja verbien vartalotyyppeihin kuuluvien supistumavartaloiden esittelyyn. Murretutkimusten äänneopillisessa osassa supistumiseen on sisällytetty kaikki eri tavoin kehittyneet supistumavokaalit ja -diftongit siitä riippumatta, onko kyse varhaisesta vai myöhäisestä konsonantin kadosta vai kadon vuoksi syntyneen vokaaliyhtymän assimilaatiosta: seuraan, nään, (рари :) paun, joen, (mennä :) mään; vaikee, lähtiissä, vastaos. Yhteistä näille supistumille on se, että eri tavuihin kuuluneet vokaalit ovat yhtyneet samaan tavuun. Prosessia kuvataan toisinaan verbillä vetää: vokaalit vedetään kokoon, yhteen, pitkäksi tai diftongiksi (esim. Salonius 1881: 262; Hannikainen 1886: 114).

Johdokset heittyminen ja supistuminen eivät ole ainoita yleisnimityksiä, joiden alakäsitteiksi on koottu erilaisia murrepiirteitä. Vielä yleisempiä ilmauksia ovat lähes kaikissa tutkimuksissa esiintyvät verbit muuntaa, muuntua, muuttaa ja muuttua nominijohdoksineen (esim. 17-20). Niillä on kuvattu varsinkin vokaaliston piirteitä, kuten diftongiutumista (moa, peä) ja labiaalistumista (laskoo, lähtöö), mutta ne ovat sopineet mihin tahansa murteen ja kirjakielen välisiin eroihin.

(17) ee muunnetaan ei:ksi ainoasti sanassa eistää. (Lönnbohm 1879: 14)

(18) Pitkä $a$ ja $\ddot{a}$ ovat monessa kohdin muunnoksen alaiset, paitsi jo mainittua muuntumista oa:ksi ja eä:ksi sanana ensi tavuussa, myöskin etempänä ensimmäistä tavuuta. (Brax 1890: 236) 
(19) Alkuperäinen -ea (-eä) on joskus nominivartalojen lopussa muutettu -ia:ksi [makia]. (Lindfors 1893: 7)

(20) $\quad N$ muuttuu $m: k s i$, jos $m$ tai $p$ seuraa [empä] - -. (Lindfors 1893: 14)

Lähellä muuntaa, muuttaa -sanastoa ovat verbit vaihtaa ja vaihtua nominijohdoksineen (vaihtaminen, vaihdos, vaihtuminen). Äänteiden vaihtaminen tai vaihtuminen on monissa tutkimuksissa omana lukunaan, ja siinä esitellään sanoja, jotka eroavat kirjakielestä tai muista murteista yhden äänteen, äänneyhtymän tai keston puolesta. Irrallisten tapausten (niittu, männä) lisäksi mukaan on otettu esimerkkejä laajemmista äänneilmiöistä, kuten metateesista (pihjala), tavunloppuisista klusiileista $($ lalv = latva), klusiilien soinnillistumisesta $($ lang = lanka) sekä keston vaihteluista $(p y h-$ kiä). Luettelot vaihtelevat murteittain, koska ryhmään on koottu sellaiset piirteet, joita ei ole pystytty sijoittamaan muualle tai analysoimaan tarkemmin.

Ilmausten polysemia ja synonymia, yhden piirteen kuvaaminen monin eri ilmauksin ja saman ilmauksen käyttö monesta eri piirteestä, ovat tuttuja ilmiöitä myös nykyisessä kansanlingvistisessä metakielessä (Mielikäinen \& Palander 2014: 183-184, 240). Ne kertovat molemmissa metakielissä valmiiden nimitysten puutteesta ja sanaston vakiintumattomuudesta. Polysemian on todettu liittyvän nimenomaan erikoiskielten syntyyn eli vaiheeseen, jossa kategoriat ja merkitykset ovat vielä eriytymättömiä (Laine 2007: 74, 300). Murretutkimusten sanastossa on selvästi termiytyneitä yhden piirteen nimityksiä (svaa, liudennus), mutta myös useista piirteistä käytettäviä sanoja, joiden termiysaste vaihtelee. Termintutkimuksessa on joskus erotettu teoreettisten termien lisäksi primitiivitermit ja pragmaattiset käyttötermit, joita ei yleensä määritellä. Edelliset ovat jo vanhastaan käytettyjä ilmauksia, jälkimmäiset tiuhaan esiintyviä terminomaisia sanoja. (Karihalme 1996: 148; ks. myös Pitkänen 2008: 122-123.) Murteentutkimuksen metakieleenkin kuuluu termiysasteeltaan useammanlaisia sanoja. Ennestään tuttuja primitiivitermejä olisivat esimerkiksi sana ja muoto, yleiskielestä saatuja pragmaattisia käyttötermejä muutos, pidetä ja lyhetä. Joitakin sanoja käytetään polysemiansa vuoksi sekä termiytyneinä nimityksinä että eri yhteyksiin sopivina käyttötermeinä: astevaihtelun nimityksenä pehmeneminen (pehmetä) on selvä termi, mutta pehmetä-pesyettä voidaan käyttää laajemminkin mistä tahansa äänteiden heikkenemisestä. Pragmaattisten käyttötermien avulla murteentutkijat ovat ryhmitelleet samankaltaisia kielenpiirteitä ja jäsennelleet ja otsikoineet tutkimuksensa. Otsikoissa toistuvat sellaiset konsonanttien tai vokaalien piirteitä ilmaisevat termit kuin heittyminen, lisääminen, supistuminen, lyheneminen, piteneminen, muuttuminen ja vaihtuminen tai muut näitä vastaavat johdokset: Konsonanttien vaihtuminen ja muuttuminen, Konsonanttien poisheitto, Vokaalien supistuminen, Vokaali-ainesten lisäytyminen. Osa näistä sanoista on väistynyt, osa säilynyt edelleen kielentutkimuksen käyttötermeinä. Murreilmiöiden tarkoiksi nimityksiksi ne eivät yksinään riitä, mutta teoreettisia termejä niistä on voitu tehdä tarkentavilla määritteillä (esim. sijaispidennys, geminaattanasaalien lyheneminen). 


\section{2 Ääntämyksen kuvailuja}

Foneettisen termistön osuus oli murteentutkimuksen alkuvaiheessa vähäinen. Suomen kielen äänteistä oli olemassa jonkinlaisia foneettisia kuvauksia jo 1840-luvulla (Häkkinen 2008: 141), ja kieliopit tarjosivat mallia konsonanttien ja vokaalien ryhmittelyihin (esim. Eurén 1852: 21). Ajan mittaan murretutkimusten viitteisiin ilmaantuivat Genetzin äännefysiologiset tutkimukset sekä 1880 -luvun lopulla Eduard Sieversin fonetiikan perusteos. Analyyseissa vilahteli varhain artikulaatiopaikan ja -tavan mukaisia äänteiden nimityksiä (esim. kieliäänne, liqvida). Kirjakielen kirjainten riittämättömyys murteiden litterointiin huomattiin jo 1870-luvulla, mutta äänteiden keston tai laadun väliasteille ei ollut vielä riittävästi transkriptiomerkkejä. Grotenfelt (1878: 311) aloittaa koko tutkimuksensa tällä ongelmalla: murteen kirjaintaminen on vaikeaa, koska tutkija "kuulee usein kansan suusta ääniä ['äänteitä], jotka ovat niin sekaisia, niin kahden varman äänen välissä, että hän ei tiedä, millä kirjaimella hänen pitää merkitä se ääni”.

Vähitellen eteneviä muutoksia, kuten geminaatiota ja diftongien avartumista tai redusoitumista, tarkastellaan foneettisesti vasta äännehistorioissa, mutta vertailevan kauden tutkimuksissa on jo useita havaintoja varianttien väliasteista. Niitä kuvataan ääntämyksen ilmiöinä (lausua, ääntää) tai kuulohavaintoina (kuulua, vivahtaa), ja yleinen apusana on melkein. Esimerkiksi yleisgeminaatiossa, joka ei ole vielä edennyt foneettisesta fonemaattiseksi, konsonantti "lausutaan melkein kaksinkertaisena" (Hannikainen 1886: 111) tai "äännetään puoli-, harvemmin koko-pitkäksi” (Reijonen 1893: 14). Itämurteiden erikoisgeminaatiosta ei ole mainintoja, ja tämä joskus "laajentuneeksi geminaatioksi” nimitetty ilmiö onkin melko myöhäinen (Kettunen 1940: kartta 2; Palander 1987: 11, 28-33). Foneettisiin variantteihin viitataan myös diftongien kuvauksissa. Pitkän $a: n$ ja ä:n diftongiutumisastetta osoittaa ilmaus, jonka mukaan oa ja eä (moa, peä) "kuuluvat välistä melkein kuin ua ja iä" (Hannikainen 1886: 110). Vastaavanlaisia ilmauksia on diftongien avartumisesta ja redusoitumisesta. Halikon murteen uo, yö, ie -diftongien avartuva jälkikomponentti vivahtaa Toivosen mukaan (1889: 127) seuraavan tavun $a$ :han tai ä:hän: "tuoma (melkein: tuama)". Redusoituneet diftongit ovat Keski-Suomen murteissa vanhojen puheessa selvät (täötyy), mutta nuoremmilla ne "kuuluvat melkein niin kuin KK:ssä [kirjakielessä]" (Grotenfelt 1878: 318). Tarkemmin reduktiota on kuvannut Brax (1890: 230) vuosikymmentä myöhemmin: Pohjois-Savon murteessa $i, u, y$-loppuiset diftongit äännetään avoimesti, niin että jälkikomponentti on "melkein selvä $o, \ddot{o}, e$, mutta sekin hyvin lyhyenä": kaola, saeras. Sekä Brax että Rei-

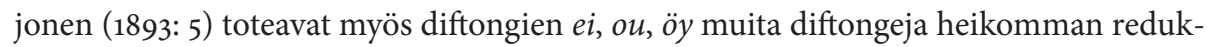
tion. Havainto vastaa myöhempien tutkimusten tuloksia savolaismurteiden diftongeittaisista eroista (esim. Mielikäinen 1994: 79-81).

Tutkijoiden huomiota ovat lisäksi kiinnittäneet joidenkin yksittäisten äänteiden ääntämykset. Jotain vokaalia on kuvattu ohueksi, toista leveäksi. Se, että loppuheittomurteessa loppuvokaali on säilynyt joskus kuiskeena $\left(\right.$ korpp $\left.^{u}\right)$, viitannee soinnittomaan vokaaliin (ks. esim. Toivonen 1889: 130). Konsonanteista on mainittu $r$ ja $n$. Edellinen äännetään $d: n$ vastineena länsimurteissa "kuin hieno $r$ " (Salonius 1872: 90) tai "pehmeän $r$ :n tavalla" (Almberg 1870: 112), ilmeisesti siis yksitäryisenä. Tornion murteiden $r$ :n kuvaus vastaa lähinnä soinnillista dentaalispiranttia (vrt. Kettunen 1940: kartta 65): 
se ei ole "niin kuin puhdas r, vaan niinkuin d ja r olisivat yhdessä", ja alueittain se otetaan "niin keveästi kielen kärjellä hampaita vasten, että se juuri parahiksi äänen kannattaa" (Salonius 1881: 259). Sananloppuisen $n$ :n on todettu tummentuvan tai muuttuneen tummaksi, ja joissakin tapauksissa $n$ saatetaan ääntää nenä-äänenä, nenän läpi tai nenän kautta (Grotenfelt 1878: 324-325; Almberg 1870: 112; Chydenius 1886: 106). Näissä Keski-Suomen ja Etelä-Pohjanmaan murteita käsittelevissä kuvauksissa on ehkä tavoiteltu s:n edellä redusoituneen $n: n$, nasaalisen $s: n$ tai nasaalivokaalin ääntämystä.

Vaikka suomalais-ugrilainen tarkekirjoitusjärjestelmä luotiin vasta vuosisadanvaihteessa, sukukielten ja murteiden kirjaintamiseen oli kiinnitetty huomiota aiemminkin, muun muassa Genetzin tutkimuksissa (Häkkinen 2008: 142-143). Myös 1870-1880-luvun murretutkimuksissa on pyritty merkitsemään sellaisia kestoja ja ääntämyksiä, joihin pelkkä kirjaimisto ei riitä. Rivinylisen kirjaimen käyttö diftongin $i$ :n ja svaan lyhyemmän keston osoittamiseksi (kulu ${ }^{i}$ vel $\left.{ }^{e} h o\right)$ on säilynyt nykytranskriptiossakin. Tämän lisäksi joillakin kirjoittajilla on omia käyttötapoja rivinyliselle ja rivinaliselle kirjaimelle. Niitä käytetään merkitsemään esimerkiksi vaillinaista yleisgeminaatiota, svaan kestoa ja loppukahdennusta: $\mathrm{ru}^{k} k i i n$, tal ${ }_{a}$ koot (Reijonen 1893: 14, 10); tänne j juoks (Grotenfelt 1878: 324). Diakriittisistä merkeistä yhdenmukaisimmalla ja systemaattisimmalla tavalla on käytetty liudennusta osoittavaa akuuttia (sanoń). Joissakin tutkimuksissa on muitakin lisämerkkejä, esimerkiksi n:n ääntämyksestä: talosa ${ }_{a} \dot{s} a$ ("nenä-ääni"; Almberg 1870: 112), veljeṇsä, jollenkka ("tummentunut $n$ " ja "kurkku-ñ"; Grotenfelt 1878: 325). Hannikainen (1886) on osoittanut Parikkalan murteen geminaation vaillinaisuuden aina pitkän keston merkillä (min̄uu), ja Reijonen (1893) on merkinnyt $e i, o u, \ddot{o} y$-diftongien jälkikomponentit säännöllisesti suppeiksi (leépä, poota, köŏhä). Reijonen mainitsee "puoli-umpinaiset" vokaalit $\dot{e}, \dot{o}, \breve{o}$ myös Nurmeksen murteen äänneluettelossa (mts. 4).

\section{Metakieli ja 1800-luvun kirjasuomi}

Tieteellisen kielen kehittämisessä pyrittiin 180o-luvulla ajan hengen mukaisesti omaperäisyyteen. Puristisiin tavoitteisiin vaikuttivat Euroopassa laajemminkin kansallisromantiikka ja kansallisuusaate. Suomen oloissa eri tieteenalojen omakielisen sanaston katsottiin muun muassa nostavan suomen kielen statusta ja hyödyttävän kansan sivistämistä erityisesti oppikirjojen kautta. (Pitkänen 2008: 17, 277.) Oman kielen merkitystä korostettiin muutenkin, ja kansalliset ihanteet saattoivat näkyä tieteenkin kielessä. Seuraavassa tarkastelen metakieltä ensin 1800 -luvun sanastonkehityksen valossa (luku 4.1), sitten aikakauden tyylillistä ja ideologista taustaa vasten (luku 4.2).

\subsection{Vierasperäinen ja omaperäinen sanasto}

Yleiskielen sanastoon verrattuna erikoisalojen sanastoilla on takanaan erilainen kehitysprosessi, sillä niissä on kyse käsitteiden ja käsitejärjestelmien hahmottamisesta ja tietoisesta kielentämisestä. Varhaisnykysuomen aikaisille kielen kehittäjille ja sanaston luojille käsitteet olivat usein tuttuja muista kielistä. (Laine 2007: 41-42.) Kielioppi- 
termien suomentamisen aloitti Elias Lönnrot, joka laati sanastoja muillekin erikoisaloille. Kielioppeihin luotiinkin 180o-luvulla kokonaan omakielinen termistö, mutta se vaihteli jonkin verran tekijöittäin. ${ }^{8}$ (Häkkinen 2000: 194-195, 197.) Näin ollen murteentutkijoilla ei ollut yhtenäistä erikoissanaston mallia, ja paria tutkijaa (Hahnsson, Aspelin) lukuun ottamatta kaikki ovat käyttäneet sanaluokista ja taivutuskategorioista latinaan pohjautuvia termejä: substantiivi, essiivi, komparatiivi, pronomini, verbi, imperfekti, partisiippi ja niin edelleen. Lähes yksinomaisia ovat myös termit konsonantti, vokaali ja diftongi ${ }^{9}$.

Kieliopeista omaksuttuja vierassanoja on myös murrepiirteiden kuvauksissa: aspiraatio 'loppukahdennus, jäännöslopuke', assimilaatio, kontraktio 'supistuminen'. Piirteiden varsinaisissa nimityksissä on joitakin myöhemmistä äännehistorioista tuttuja vierasperäisiä termejä, kuten muljeeraus (muljeerata, muljeerautua) 'liudennus', svaa ja elisio. Muljeerata-pesyeen etymologinen tausta on ranskan kielen verbissä mouiller 'pehmentää' (Bußmann 1990 s. v. Mouillierung), ja kielitieteen terminä sillä on vastineensa myös ruotsissa ja saksassa (muljera, mouillieren). Saksan kielestä omaksuttu sitaattilaina schwa (< hepr. šəwa) tarkoittaa fonetiikassa painotonta neutraalia vokaalia. Suomalaisessa murteentutkimuksessa sen rinnalla on 1900-luvun alussa käytetty eritaustaista termiä svarabhakti (< sanskr.), joka tarkoittaa anaptyktistä, tavua muodostavaa vokaalia. (Ravila 1966: 34; Bußmann 1990 s. v. SchwaLaut, Svarabhakti. ${ }^{10}$ ) Vaikka termit ovat erimerkityksisiä, ne on suomalaistutkimuksissa rinnastettu, kun on puhuttu "svaa- eli svarabhaktivokaalista" (esim. Ravila mp.; Tarkiainen 1904: 24; Itkonen 1966: 170). Käyttöön niistä on kuitenkin jäänyt vain svaa(vokaali). Suomen murteiden välivokaali muistuttaa kumpaakin mainittua vokaalia: se on painoton, toisinaan myös ylilyhyt, eikä se muodosta tavua, mutta se on silti heterorgaanisten konsonanttiyhtymien ääntämystä helpottava epenteettinen loisvokaali kuten svarabhakti.

Termiä elisio käytetään 180o-luvun murretutkimuksissa loppuheitosta, siis hiukan laajemmassa merkityksessä kuin myöhemmissä äännehistorioissa (ks. lukua 3.1). Sillä on ollut rinnallaan samakantainen verbi elideerautua 'kadota, heittyä, joka on kielitieteessä jäänyt pois käytöstä (vrt. kuitenkin NS s. v. elidoitua 'heittyä' loppuvokaalin kadosta). Väistyneisiin termeihin kuuluu myös liudennuksen yhteydessä käytetty diluutio ${ }^{11}$ (dilu-

8. Koranterilla (1845) ja Eurénilla (1852) on suomenkielinen termistö, Ahlqvistilla (1877) ja Genetzillä (1881) vierasperäinen, mutta Ahlqvist esittelee sijamuodot myös suomeksi. Sijamuodot ovat Koranterilla ntA-johtimisia, Eurénilla ntO-johtimisia, ja Ahlqvist käyttää sija-loppuisia yhdyssanoja (esim. olenta olento yleinen olosija 'essiivi'). Eroja on myös johdosten kantasanoissa. Omaperäiset nimitykset eivät lopulta kuitenkaan säilyneet kieliopeissa.

9. Nykytermeistä poiketen konsonanttiyhtymistä erotettiin joskus konsonanttidiftongit ja -triftongit, joilla tarkoitettiin samaan tavuun kuuluvia konsonantteja, kuten sananalkuisissa konsonanttiyhtymissä tai tavunloppuisissa yhtymissä: klasi, skriivari; kalske, tyrskyy (esim. Almberg 1870: 112; Chydenius 1886: 106; Cannelin 1889: 16). Konsonanttidiftongeihin saatettiin lukea myös ks, ps ja ts, koska ilmavirta katkeaa ääntämyksessä klusiilien edellä ja konsonantit joutuvat tavallaan samaan tavuun (Cannelin mp.; Almberg mp.).

10. livosen, Horppilan, Heikkosen ja Rissasen laatimassa Fonetiikan perussanastossa (FP) on näille kahdelle ilmiölle hakusanat shvaa-vokaali (schwa) 'painottomassa asemassa esiintyvä keskivokaali' (esim. engl. sanassa banana) ja epenteettinen vokaali 'konsonanttiyhtymän keskelle syntynyt loisvokaali' (esim. halapa).

11. Vierassanoihin perustuvista io-nomineista vaihtelevat erilaiset äänne- ja kirjoitusasut: dilutioni 
tioni, dilutsiooni, dilueeraus, dilueerautua < lat. diluo 'liuottaa, ohentaa, sulattaa, heikentää). Sanapesyeellä on tarkoitettu liudentunutta konsonanttia edeltävän vokaalin $i$ :mäistä ääntämystä. Grotenfeltin mukaan $(1878: 313,319)$ i:n loppuheiton yhteydessä "konsonantti saa muljeerauksen" ja sen edellä oleva vokaali "i:n-sekaisen äänen, dilueerautuu" (nuoŕ); painottoman tavun $i$-diftongin $i$ kuuluu puolestaan "edellä käyvän vokaalin dilutionina", jota yleensä seuraa muljeeraus (jalośta). Hyyryläisellä ei ole enää diluutiotermiä, mutta hän käsittelee konsonanttien muljeerauksen ja vokaalien palataliseerauk-

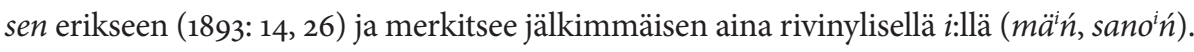
Dentaalikonsonanttien ääntämispaikan muutosta kuvaava palataalistua-verbi $(<$ lat. palatum 'kitalaki') tulee johdoksineen käyttöön varsinaisesti vasta äännehistoriallisissa tutkimuksissa. ${ }^{12}$ (Liudennuksesta tutkimuskohteena ks. Mielikäinen 2004: 510-512.)

Vaikka kielioppitermit ovat murretutkimuksissa vierassanoja ja myös monilla murrepiirteillä on vierasperäinen nimitys, tutkijoiden pyrkimys omaperäiseen metakieleen on selvä. Piirteiden kuvailut ovat kauttaaltaan suomenkielisiä, ja termimäisissä nimityksissäkin vierassanoilla on miltei aina yksi tai useampia omaperäisiä vastineita. Rinnakkaistermien käyttösuhteissa on jonkin verran vaihtelua. Esimerkiksi supistuminen (supistuma, supistua) on huomattavasti yleisempi kuin kontraktio, ja muljeeraus ja elisio on samoin korvattu usein suomenkielisillä vastineilla. Harvinaisiksi tai tilapäisiksi jäävät sen sijaan aspiraation suomennokset hengähdys, loppuhengähdys ja loppuhenkonen sekä assimiloitumisesta käytetty verbi yhtäläistyä. Vierasperäisten termien kääntämisvaikeuksista kertoo Cannelinin alaviite (1889: 12), jossa hän toteaa, ettei ole keksinyt artikulaatiolle "täysin soveltuvaa suomalaista nimitystä".

Omaperäinen sanasto on uuden tutkimusalan vuoksi kokonaan uudissanastoa, tosin osaksi kielioppien välityksellä saatua. Nekin sanat, jotka ovat olleet käytössä jo vanhassa kirjasuomessa tai murteissa, ovat saaneet tieteellisessä kontekstissa uuden erikoismerkityksen. Esimerkiksi verbien kertoa ja liutua merkitykset ovat sopineet hyvin geminaation ja muljeerautumisen kuvauksiin (ks. lukua 3.1). Vanhan kirjasuomen perua on myös raueta, jota murteentutkijat käyttävät käsitellessään varianttien väistymistä. Äänteiden kadosta käytetty verbi heittyä ja astevaihteluun ja $i$-diftongin $i$ :n lyhenemiseen viittaava vienota (vienontua) 'heiketä' ovat kirjasuomessa ilmeisesti 180o-luvun uudistulokkaita. Verbistä heittyä on pari tietoa murteista ('heittäytyä; SMS), ja sanakirjojen perusteella se on säilynyt sekä yleis- että erikoiskielessä ('viskautua, sinkoutua; kadota’; NS, KS). Vieno-kantaisia verbejä ei ole enää nykykielen sanakirjoissa (vrt. Lönnr. s. v. vienontua, vienota). Tietoisesti luotuja mutta yksinäistapauksiksi jääneitä sepitteitä ovat Toivosen käyttämät johdokset iistyä ja jiistyä 'muuttua $i$ :ksi, muuttua $j$ :ksi' $(1889:$ 126, 128)..13

dilutsiooni, aspiratio aspirationi aspiratiooni aspiratsiooni. Vierasperäiset verbit ovat puolestaan ruotsin mallin mukaisesti eerata, eerautua -johdoksia: aspireerata, aspireerautua.

12. Myöhempään termistöön kuuluvat myös sellaiset vierassanat kuin geminoitua, labiaalistua, diftongiutua ja redusoitua sekä näitä vastaavat nominit. Diftongiutuminen tunnetaan terminä kuitenkin jo 1870-luvun tutkimuksissa, vaikka yleisimmin sen sijasta käytetään muutosta ilmaisevaa sanastoa (ks. lukua 3.1): diftongiseeraus (Lönnbohm 1879: 12; Hyyryläinen 1893: 12), diftongiseerattu (Grotenfelt 1878: 316).

13. Toivosen mukaan $(1889: 126,128)$ lounaismurteissa on "eä-päätteisissä" verbeissä "useinkin $e$ i:stynyt ja -iä sitte supistunut $i(i): k s i "$, ja makja, pimjä -asuisissa nomineissa on tapahtunut e:stä syntyneen "i:n j:styminen". 
Murretutkimusten sananvalinnoissa käännöslainoilla ei ole ehkä yhtä suurta merkitystä kuin muissa 180o-luvun uudissanoissa. Kielioppien murrehavainnot olivat vähäisiä, eikä muunkielisissä kieliopeissa ollut riittävästi tarvittavaa sanastoa käännettäväksi. Suomen murteistakin oli ilmestynyt ennen 1870-lukua vain pari suppeaa ruotsinkielistä esitystä. Joissakin tapauksissa ruotsin kielen vaikutus on ollut selvä, mutta aina ei vastineeksi ole valittu suoria käännöksiä (vrt. esim. bortkasta 'heittää pois, kadota' ja förmildring 'pehmeneminen', fördubbling 'kertominen'). Suomen murteiden äänneoppi oli kirjakieleen verrattuna siinä määrin erikoistunut tutkimuskohde, ettei siinä voitu tuolloin hyödyntää eri kielten yhteistä käsitteistöä samassa määrin kuin muilla tieteenaloilla (vrt. Laine 2007: 41; Pitkänen 2008: 220). Sen sijaan muun kasvavan sanaston tapaan murretutkimusten termistölle on tyypillistä vaihtelu ennen johdosten ja merkitysten vakiintumista. Esimerkiksi 'äännettä’ vastaa aivan alkuvaiheessa kirjoitetun kielen termi kirjain, sen jälkeen ääni (samoin äänioppi) ja lopuksi 180o-luvun uudissana äänne (äänneoppi). Ilmaukset omituinen ja omituisuus toistuvat lähes kaikissa tutkimuksissa 'murteelle tyypillisen (piirteen)' merkityksessä, ja niiden synonyymeina esiintyvät huomattavasti harvemmin ominainen ja ominaisuus. ${ }^{14}$ Johdostyyppien vaihtelu ilmenee myös konsonantti- ja vokaaliyhtymän nimityksissä, joissa yleisin on $y h$ distys, harvinaisia yhteys ja yhtymä: konsonanttiyhdistys, konsonantin yhteys, vokaaliyhtymä. Johdosten vaihtelu on ollut 1800 -luvulla tyypillistä muidenkin erikoisalojen synonyymisille oppisanoille, ja vaihtelua on ollut myös yhdyssanojen ja sanaliittojen kesken (ks. Laine 2007: 362).

Uudissanojen sepittämisessä ja käytössä murteentutkijat hyödynsivät joitakin itämurteisia johdostyyppejä. Aiemmin käytettyjen länsimurteisten refleksiivisten (automatiivisten, translatiivisten) verbijohdosten rinnalle tulivat 180o-luvulla itämurteiset $u t u, y t y$-johdokset. Näillä on murteissa ja vanhassa kirjasuomessa useita vastineita (mm. jakaantua, jakauntua, jakauda; Rapola 1965: 310-312). Ahlqvistin tiedetään edistäneen uuden johdostyypin käyttöä (Häkkinen 1994: 431), ja aineistoni perusteella murteentutkijat suosivatkin sitä selvästi; lähes yksinomainen se on vierasperäisten eerata-verbien edelleenjohdoksissa: kertoutua 'geminoitua', sulautua, hupeutua ( $<$ huveta) 'heikentyä, lyhentyä, tekeytyä 'kehittyä, lisäytyä, ilmautua, esiytyä; assimileerautua (esim. 21-22).15 Tyyppi jakaantua, joka oli 180o-luvulle tultaessa päässyt kirjasuomen valtatyypiksi, on näiden rinnalla harvinaisempi (lisääntyä, ilmaantua, sekaantua). Jotkut tutkijat käyttävät muitakin variantteja: jakauntua, rappeuntua, sulkeuntua; ilmauda, jakauda, ilmauma, sulauminen (esim. 23).

(21) Adessiivin $l l$ on hupeutunut yksinkertaiseksi adverbeissa siälä, täälä ja tuala - -. (Leino 1890: 267)

14. Termit äänne ja äänneoppi ovat kirjasuomessa 1840- ja 1850-luvun tulokkaita; omituinen ja ominainen ovat esiintyneet kirjakielessä jo 1700-luvulla, mutta nykymerkityksensä ne saivat 1800-luvulla. Sen sijaan omituisuus ja ominaisuus ovat 1800-luvun puolivälin uudisjohdoksia, samoin piirre nykymerkityksessään. (Jussila 1998; Rapola 1960.)

15. Itämurteiseen asuun muunnettu hupeutua vastaa siellä täällä länsimurteissa tunnettua johdosta hupeentua (hupeintua, hupeuda, hupeuntua) 'vähentyä, huveta' (SMS s. v. hupeentua). Verbi esiytyä ja sen tilalle vakiintunut esiintyä ovat 1800-luvun uudissanoja (Rapola 1960). 
(22) Loppu-aspiratsiooni esiytyy usein myös $k$ :na, missä se on alkuperäinen - (Reijonen 1893: 13).

(23) - - ehkä ['vaikka'] kyllä luulisi myös n:n, r:n, s:n ja t:n muljeerauntuvan - (Westerlund 1883: 191)

Johdostyypit jakauda ja jakauntua näyttävät vastaavan tutkimuskohteina olevien murteiden edustusta (vrt. Rapola 1966: 170, 438-439): niistä on esimerkkejä eteläpohjalaisten ja peräpohjalaisten murteiden sekä kaakkoismurteiden ja kaakkoishämäläisten murteiden tutkimuksissa. Koska länsimurteisiin perustuvaa vaihtelua oli ollut jo vanhassa kirjasuomessa, eri tyyppien käyttö on ymmärrettävää, ennen kuin kirjakieleen vakiintuivat vain läntinen jakaantua ja itäinen jakautua.

\subsection{Metakieli aikakauden tyylin ja ideologian ilmentäjänä}

180o-luvun loppuvuosikymmenien kirjakieli samoin kuin eri tekstilajit ja niissä käytetyt tyylit eroavat huomattavasti nykysuomesta. Esimerkiksi nykyiseen tiedotukseen verrattuna uutisten on osoitettu muistuttaneen tuolloin kertomuksia ja olleen ilmaisutavaltaan affektisempia ja subjektiivisempia (Kalliokoski 1995). Tieteellinen kieli oli puolestaan kansantajuisempaa, koska erikoisalat olivat vielä eriytymättömiä ja kielenkäyttöön vaikutti samanaikaisesti kielitieteessä vallinnut purismi (Huumo 2005: 57, 59). Uusia termejä otettiin suoraan murteista eli 1800 -luvun "arkikielestä", kun yhtenäistä, tarkkaan normitettua yleiskieltä ei nykymerkityksessä vielä ollut (Laine 2007: 83). Kansallisideologia vaikutti myös erikoisalojen kieleen, ja kansallisissa tieteissä sillä oli tavallista suurempi rooli (Huumo 2005: 49; Laine 2007: 378-379). Suomen kielen oppihistoriassa on kansallisromanttisen orientaation todettu ohjailleen varsinkin Setälästä lähtien koko fennistiikan sisältöä ja tutkimussuuntia (Kelomäki 2009: 16-18). Siksi on aiheellista katsoa, paljastaako ensimmäisten murretutkimusten metakieli 1860-189o-luvun tieteellisestä tyylistä ideologisia sävyjä.

Ilmaisutavaltaan ensimmäiset suomenkieliset murretutkimukset muistuttavat kielioppeja, onhan ne laadittukin mahdollisimman pitkälle näiden mallin mukaan ja näihin vertailemalla. Tyyli on tiivistä, toteavaa ja paikoin luettelomaista. Nykytutkimukseen verrattuna kielessä on kuitenkin kansanomainen sävy, joka liittyy sanastoon. Murrepiirteiden kuvauksissa on turvauduttu sanoihin, joiden tyylisävyille ei ollut vakiintuneita määrittelyjä eikä ohjeistusta. Monet ilmaukset vastaavat kansanomaisuudessaan tai puhekielisyydessään täysin nykyistä ei-kielitieteilijöiden metakieltä. Varsinkin ensimmäisten tutkimusten arkiset sananvalinnat ilmentävät tieteellisen tyylin alkukankeutta ja erikoissanaston puutetta. Esimerkiksi Koskisen mukaan (1852: 50-51) joitakin Hämeenkyrön murteen sanoja sanotaan toisissa murteissa eri tavalla ja ea, eä -yhtymät puhutaan aina ee:ksi. Vanhimpien tutkimusten (Koskinen 1852; Warelius 1855; Almberg 1870) kielenkäytölle tyypillisiä ilmauksia ovat venyttääpesye (venyttäminen, venytys) pidentämisestä, loppuheittoon viittaava verbi katkaista 'lyhentää' sekä svaasta ja siirtymä-äänteistä käytetyt ilmaukset pistää väliin ja lykätä väliin, välille tai sisään 'lisätä. Äänteiden katoamisen vastakohtaa ilmaistaan myöhem- 
missäkin tutkimuksissa verbillä säilyä mutta myös ilmauksilla pysyä tai pysyä paikallaan (paikoillaan), pitää paikkansa ja jäädä olemaan. Puhekielistä sävyä vahvistavat murrepiirteistä käytetyt ekspressiiviverbit: haihtua, putoilla, rapista pois, karista pois tai karistaa pois (äänteiden kadosta) ja pujahtaa tai pujahduttaa (svaasta). Ekspressiivisanoilla on vankka asema myös nykyisessä kansanlingvistisessä sanastossa, niin kielenpiirteiden kuin varsinkin puhetavan ja eri murteiden kuvauksissa. (Vrt. Mielikäinen \& Palander 2014: 142, 165-168, 223.)

Vanhojen murretutkimusten kielenkäyttö sisältää nykykieleen verrattuna myös affektissävyisiä, esteettisesti kuvailevia tai arvottavilta vaikuttavia ilmauksia. Murteessa yleisiä, kaikkien käyttämiä variantteja saatetaan sanoa arvossa pidetyiksi (Grotenfelt 1878: 315) tai rakastetuiksi (Hannikainen 1886: 110), ja ilmiön tai variantin käytön ehdottomuutta tai ehdotonta käyttäjää kuvataan ankaraksi (Lönnbohm 1879: 4, 5). Samantapaista affektista ja evaluoivaa ilmaisua on 180o-luvun lopun uutiskielessäkin. Sille on etsitty laajempia yhteiskunnallisia ja ideologisia syitä; uutisilla on tuolloin ollut paitsi tiedottava myös valistava ja viihdyttävä funktio. (Kalliokoski 1995: 43-44.) Nykyisessä kansanlingvistisessä metakielessä tunnepitoisia sanoja käytetään runsaasti ilmaistaessa asenteita murteisiin, kielenpiirteisiin tai murteenpuhujiin (Mielikäinen \& Palander 2014: 27, 79). 1800-luvun murteentutkijoiden sananvalinnat saattavat sen sijaan heijastella yleisemmin koko aikakaudelle tyypillisiä tyylivaihteluja, sillä tutkimuksista puuttuvat sekä viihteellinen funktio että subjektiiviset asenteiden ilmaukset. Teksteissä ei ole juuri kansallisideologiaan vihjaavia kuvauksia murteiden arvottamisesta (kaunis, rikas), ja esimerkiksi rikkaana pidetään parissa tutkimuksessa vain murteen pääte- tai johdinvarianttien valikoimaa. On myös huomattava, että monet vanhan kirjasuomen ja varhaisnykysuomen sanat ovat muuttuneet merkitykseltään tai tyylisävyltään. Esimerkiksi kaakkoismurteiden superlatiivin vahvikesanaa kaikkii 'kaikkein' (kaikkii vanha tai vanhemp) on Lönnbohm (1879: 34) luonnehtinut tenhokkaaksi, mutta uudisjohdos tenhokas tarkoittanee tässä yhteydessä vain sanan vaikuttavuutta (vrt. Lönnr. s. v. tenhollinen myös 'verkande, kraftig'; NS s. v. tenhokas 'tenhoava', tenhoava 'kiehtova, lumoava, hurmaava'). "Koron loistavin vaikutus" on puolestaan viitannut painon selvimpään, näkyvimpään vaikutukseen yleisgeminaatiossa (Lönnbohm 1879: 18), ja savolaismurteiden etevimmät muutokset ovat olleet pisimmälle menneitä muutoksia (Aminoff 1876: 193; vrt. Lönnr. s. v. etevä: etevin 'förnämst, främst, längst kommen'). Kun sanasto kasvoi nopeasti, tarjolla oli sekä vanhaa että uutta, ja merkitykset samoin kuin eri tekstilajeihin sopivat tyylisävyt vakiintuivat hitaasti.

Metakieli ei ole vain sananvalintoja ja termiytyneitä ilmauksia, vaan siihen kuuluvat myös syntaktiset ja tekstuaaliset seikat, kuten se, miten tekstiä rakennetaan ja millaisesta toiminnasta ja toimintaan osallistumisesta puhutaan. Murteista käytetyssä metakielessä voi tarkastella sitä, miten ilmaistaan kielen, kielenainesten, kielenkäyttäjien ja havainnoijien tai tutkijoiden suhteita. Tieteen kielelle on tyypillistä persoonattomuus. 1900-luvun äännehistoriallisessa tutkimuksessa mainitaan kielenkäyttäjät eli murteenpuhujat harvoin, lähinnä vain eri-ikäisten vertailussa. Passiivimuodotkaan eivät viittaa selvästi toimijoihin, vaan 'olemassaoloon, esiintymiseen': murteissa tavataan tai käytetään tiettyjä variantteja. Aktiivilauseiden subjektitarkoitteina ovat taas useimmiten kielenainekset, äänteet, jotka ovat passiivisia osallistujia muuttumisverbeillä ilmais- 
tuihin toimintoihin (esim. lyhetä, kadota, assimiloitua). Nykyisessä kansanomaisessa metakielessä muutoksia ja murre-eroja kuvataan paitsi passiivimuodoilla myös passiivin taakse oletettujen kielenkäyttäjien toiminnalla. Turun murteessa katkotaan sanoja, ja itämurteissa tuplataan konsonantteja, mutta toisin ilmaistuna turkulaiset katkovat tai pätkivät tai lyhentävät sanoja ja savolaiset tuplaavat konsonantteja. (Mielikäinen \& Palander 2014: 154, 167-168.)

180o-luvun murretutkimusten metakieli eroaa joiltakin osin nykyisestä tieteellisestä ja ei-tieteellisestä kielenkäytöstä. Toisin kuin äännehistorioissa passiivimuodoilla ei ilmaista pelkästään jonkin piirteen 'olemassaoloa, esiintymistä, vaan myös nykyisen maallikkokielen tapaan äänteisiin kohdistuvaa toimintaa. Äänteet muuttuvat tai niitä muutetaan toisiksi, vokaalit supistuvat tai ne supistetaan pitkiksi vokaaleiksi, ja astevaihtelussa $k$ "heitetään pois $k: n$ perästä, mutta pidetään ['säilytetään'] $s: n$ ja $t: n$ jälessä” (Aspelin 1870: 12). Monilla äänteiden muuttumista ilmaisevilla verbeillä onkin sekä transitiivinen että intransitiivinen vastine: kertoa - kertoutua, heittää - heittyä, muljeerata - muljeerautua, assimileerata - assimileerautua. Kielenkäyttäjiä vanhimmat murretutkijat mainitsevat vain satunnaisesti, tällöinkin vain eri kielenkäyttäjäryhmien vertailussa tai asenteiden havainnoinnissa. Se, ovatko murteenpuhujat kertomisen, pehmentämisen, supistamisen ja muiden muuttamistoimintojen subjekteja, jää kuitenkin epäselväksi. Murrepiirteiden kuvauksiin kuuluu nimittäin yksi toimijuus, joka puuttuu myöhemmästä tieteellisestä ja kansanomaisesta metakielestä: myös murre esitetään aktiivisena toimijana. Murre voi käyttää tiettyjä variantteja, muuttaa tai pistää väliin äänteitä ja supistaa vokaaleja. Murteelle tyypillisiä variantteja kuvataan varsinkin verbillä viljellä, ja sen vastakohtia ovat verbit karttaa ja vieroa (esim. 24-26). Samoissa asemissa käytetään vahvemmankin sävyisiä verbejä, kuten esimerkiksi sallia, kärsiä, huolia, rakastaa ja suvaita (esim. 27-30). Yleisin näistä on suvaita. Sen kielteisellä muodolla ilmaistaan fonotaktisia rajoituksia ja äännejärjestelmien fonologisia eroja, joita murteissa on kirjakieleen verrattuna muun muassa sananalkuisissa konsonanteissa sekä pitkissä vokaaleissa ja diftongeissa.

(24) Eroten kirjakielen luonteesta viljelee murre seuraavia triftongejakin - -. (Lönnbohm 1879: 3)

(25) Rakastaen sanojen venytystä yleensä, tämä [Isojoen] murre huolella karttaa kontraktionia. (Almberg 1870: 114)

(26) Pitkistä vokaaleista vieroo murre aa:ta, ee:tä, oo:ta, ää:tä ja osaksi $y y$ :täkin sanan ensimmäisessä tavuussa ja muuttaa ne sentähden diftongeiksi. (Könönen 1888: 3)

(27) Sanan alussa murre sallii kaksi konsonanttia sekä lainasanoissa että luonnonääntä matkivissa verbeissä ja näiden johdannaisissa. (Leino 1890: 266)

(28) Yksinäisiä loppukonsonantteja murre yleensä kärsii vähemmin kuin kirjakieli. (Leino 1890: 269) 
(29) Vokaali-yhdistyksiä oa, öä ei [eteläpohjalainen] murre suvaitse, vaan muuttaa ne ua:ksi, yä:ksi [sanua] - -. (Aminoff 1871: 242)

(30) Savolainen murre näyttää selvästi tahtoansa saada korollisen tavuun pitkäksi [yleisgeminaatiossa] - -. (Grotenfelt 1878: 326)

Murteen rinnalla puhutaan tutkimuksissa joskus Kielettärestä, jolla 180o-luvun keskusteluissa tarkoitettiin suomen kielen todellista olemusta ja puhtainta ilmentymää (Laitinen 2004: 177; Nordlund 2004: 286, 312-314). Kieletär pitää eräitä eteläpohjalaisia sanoja svaan takia kolmitavuisina (Aminoff 1871: 240), ja kaakkoismurteiden jonnaikiityyppisiin pleonastisiin pronominimuotoihin se on vaatinut "toista kii-sanaa koska entinen on mennyt niin kovin heikoksi ettei se ole enää kielitunnolle riittänyt" (Lönnbohm 1879: 72). Kielen personoinnilla on kytkös aikakauden kansallisideologiaan ja oman kansalliskielen merkitykseen mutta samalla yleisemminkin siihen, miten kielentutkijat tuolloin metaforisoivat kieltä. Luonnontieteiden vaikutuksesta kieli rinnastettiin elävään organismiin, joka toimii ja käyttäytyy tietyllä tavalla. (Nordlund 2004: 297-298, 314; Itkonen 1966: 32.) Murretutkimukset osoittavat saman personoinnin siir-

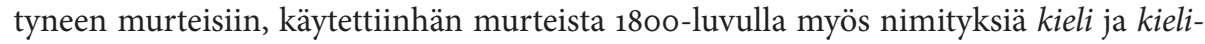
murre tai kielenmurre. Tutkimusten otsikoissa nimitysten valikoima on vielä laajempi, mutta useimmin niissä toistuu kielimurre. (Ks. Mikkola \& Laitinen 2013: 450-454; Mielikäinen \& Palander 2014: 34.)

\section{Murretutkimusten diakroninen näkökulma}

Vertailevan kauden murteentutkimus ei ollut pelkästään deskriptiivistä, synkronista tutkimusta. 180o-luvun alkupuolen komparatiivinen kielitiede oli selvitellyt vertailun avulla kielisukulaisuuksia, joten sen metodi oli oikeastaan historiallis-vertaileva (Ravila 1966: 9-11; Itkonen 1966: 30-33). Suomalaisista murteentutkijoistakin jotkut, esimerkiksi Aminoff ja Lönnbohm, viittaavat jo 1870-luvulla suomen sukukielten tutkijoihin (esim. Ahlqvist, Castrén, Genetz). Kirjakieli säilyi silti murreanalyysien perustana 1890-luvulle saakka, ja murteista pyrittiin selvittämään siitä eroavat "lait" ja "säännöt”. Näistä käytettiin tutkimuksissa myös nimityksiä äänilaki tai äännelaki ja kielilaki. Kirjakielen merkityksestä esittää Salonius tutkimuksensa johdannossa (1872: 87), että "jos murteiden vertailemalla toisiinsa tahdotaan tulla historiallisiin johtopäätöksiin, niin on erittäin huomattavat ja tärkeästi muistoon pantavat ne kohdat, missä murre yleisesti eroaa kirjakielestä’. Eri tutkijoiden esityksissä toistuvatkin sentapaiset ilmaukset kuin "KK:stä eriävällä tavalla" tai "samoin kuin kirjakielessä".

Ensimmäisiä murretutkimuksia on arvioitu myöhempien äännehistoriallisten menetelmien valossa joskus esitystavaltaan toteaviksi ja selityksiltään puutteellisiksi (esim. Nyman 1905: 78). Kritiikkiä ei voi kuitenkaan yleistää, sillä selittävän tekstin määrä vaihtelee tekijöittäin. Monien murrepiirteiden ehdot on tunnistettu ja esitelty samalla tavalla kuin historioivissa tutkimuksissa, sillä kesto ja paino (korko), tavujen rakenne sekä äänteiden ryhmittelyt olivat tuttuja kieliopillisista esityksistä. Esimerkiksi yleis- 
geminaation kuvaukset perustuvat painoon ja vokaaliainesten pituuteen aivan kuten nykyään, ja yleisgeminaation ja lounaismurteiden erikoisgeminaation säännöt on erotettu toisistaan (Salonius 1872: 92-93). Svaasta on huomautettu, että se "ei enennä tavuiden määrää" (Grotenfelt 1878: 313) tai "vaikuta mitään sivukoron siirtymistä" (Brax 1890: 235). Myös liudennus rajataan tutkimuksissa niihin asemiin, joihin se kuuluu, konsonanttien $l, n, r, s$ ja $t$ ominaisuudeksi (esim. Lönnbohm 1879: 21). Itämurteiden $i$ :n loppuheiton esteinä luetellaan murteesta riippuen $i$ :n edellä esiintyviä konsonantteja ja konsonanttiyhtymiä (esim. Könönen 1888: 4; Brax 1890: 234). Yhtä tarkasti esitellään muidenkin murrepiirteiden ehtoja, mutta toisaalta on myös ilmiöitä, joissa on äänneopillisen määrittelyn sijasta turvauduttu muotoryhmien luettelointiin. Vanhimmassa suomenkielisessä tutkimuksessa äännepiirteiden käsittely perustuu muista tutkimuksista poiketen kokonaan muoto-oppiin, ja esimerkiksi lounaismurteiden erikoisgeminaatio on tästä syystä vaatinut vartalotyyppeineen ja muotoryhmineen kolmattakymmentä sivua (Hahnsson 1866: 51-75).

Deskriptiivisestä esitystavasta huolimatta tutkimukset sisältävät monia myöhemmän tutkimuksen hyväksymiä päätelmiä äännevarianttien diakroniasta. Aminoff (1876: 197-198) vertailee eri-ikäisten varianttien avulla Vermlannin savon suhdetta Pohjois- ja Etelä-Savon murteisiin. Eteläpohjalaisista murteista hän selittää $i a$, $i a ̈$-yhtymän syntyneen alkuperäisestä ea, eä -yhtymästä ja astevaihtelutyypin jalka : jalaan kehittyneen $k: n$ pehmennyttyä ja sulauduttua seuraavan vokaalin kanssa pitkäksi vokaaliksi (Aminoff 1871: 241, 254-255). Samantapaisia selityksiä on eri tutkijoilla useista muistakin piirteistä, muun muassa itämurteiden tavunloppuisten klusiilien (otra, kakra) alkuperäisyydestä läntisiin vastineisiin verrattuna (mts. 249; Reijonen 1893: 14) ja kaakkoishämäläisten murteiden diftongiasujen peltuo 'peltoa', tyttyö 'tyttöä' synnystä assimiloituneen pitkän vokaalin kautta (Westerlund 1883: 193). Vähittäisistä äänteenmuutoksista Reijonen (1893: 14-15) on vertaillut vaillinaisen yleisgeminaation "puoli-pitkää" konsonanttia "koko-pitkään" minimiparien avulla, siis aivan nykyaikaisen foneemianalyysin tavoin: koko: kokkoon, mutta kokko: kokkoon. Havainnollisimmin historiallisen näkökulman kehitys käy ilmi eteläpohjalaisten murteiden ja itämurteiden labiaalistumisilmiön kuvauksista. Preesensmuodot laskoo, lähtöö selitetään yksinkertaisimmillaan ee:n muuttumisena (Almberg 1870: 107; Brax 1890: 237), mutta myös viereisen v:n vaikutus muodoissa laskovat, laskova on huomattu (Aminoff 1871: 241). Preesensmuotojen laskoo, lähtöö synty v:llisestä asusta tulee sekin esiin parissa tutkimuksessa (Grotenfelt 1878: 315-316; Reijonen 1893: 10). Grotenfelt (mp. alav.) esittää koko muutosketjun eviloppuisesta muodosta lähtien nykyiseen tapaan, välivaiheiden -ovi, -ov ja -ou kautta.

Useimmat murrepiirteisiin liittyvät termit näyttävät jo sellaisenaan sisältävän muutoksen aspektin: pehmeneminen, poisheitto; liutua, supistua. Poikkeamat kirjakielestä osuvat toisinaan yksiin äänteenmuutosten kanssa, sillä kirjakielen variantit vastaavat monesti alkuperäisintä murre-edustusta (vrt. esim. ea, eä -yhtymä, geminoitumattomuus, loppuvokaalien säilymä). Eri tutkimusparadigmoihin perustuvaa muuttumisen termistöä ei voi silti aina samastaa, sillä "muutokset" voivat olla kirjakielen taustaa vasten näennäisiä. Varsinkin kirjavasti käytetty vaihtua-sanasto ilmentää pelkkää synkronista vertailua kirjakieleen tai muihin murteisiin. Toisinaan kirjakielinen lähtökohta on aiheuttanut historiallisesti kyseenalaisia tai takaperoisia kuvauksia. Selitys, 
jonka mukaan diftongiutuneiden pitkien vokaalien alkukomponentti katoaa monikon tai imperfektin i:n edeltä (moa : maessa, soan : sain; Reijonen 1893: 5-6; ks. myös Lindfors 1893: 8), muistuttaa "äärisynkronisuudessaan" generatiivista kuvausta ${ }^{16}$. Äännehistoriaan se ei kelpaisi, vaikka äänteenmuutoksen selitys on näennäisesti samankaltainen; monikon $i$ :n etinen alkuperäinen pitkä vokaali on nimittäin lyhentynyt jo ennen diftongiutumista (ks. Hakulinen 1979: 39-40). Itämurteiden maihen-tyyppisestä monikon genetiivistä Brax (1890: 240) selittää, että sen "ihen-pääte" on "vienonnut alkuperäisestä -itten päätteestä". Kyse on kuitenkin eri tavoin syntyneistä analogisista päätteistä, joista läntinen -tten on hyväksytty kirjakieleenkin.

Ehkä hämmentävin on sananloppuisten konsonanttien käsittely aspiraation avulla. Aspiraatiolla on vanhoissa suomen kieliopeissa tarkoitettu jäännöslopuketta eli sananloppuisten konsonanttien, ensisijaisesti $-k: n$, aiheuttamaa loppukahdennusta tai laryngaaliklusiilia. Kieliopeissa aspiraatio on mainittu yhtenä konsonanttina ('), ja saman mallin mukaan se kuuluu myös murretutkimusten äänneluetteloon vertailevan kauden loppuun saakka. Aspiraatio on sovitettu kaikkien loppukonsonanttien murreedustukseen, ja tämä on johtanut tutkijat ristiriitaisiin selityksiin (esim. 31-35):

(31) Pohjois-Hämeen [= Keski-Suomen] murteessa on aspirationi hyvin paljon käytännössä, ja välistä se noin lauseen lopussa ja muuallakin kovenee selväksi $k$ :ksi [vaehak] - -. (Grotenfelt 1878: 323)

(32) Loppu-aspiratsiooni muuttuu seuraavan sanan tai liitännäispartikkelin alkukonsonantin kalttaiseksi [tuos se hevonen] - -. (Reijonen 1893: 13)

(33) Aspirationi (') kovenee usein sanain lopussa t:ksi [sinnet] - -. (Cannelin 1889: 13)

(34) Loppu- $n$ on muuttunut joko epäselväksi aspiratsiooniksi tai seuraavan konsonantin kaltaiseksi - -. (Leino 1890: 269)

(35) Niissä contracta nomineissa, joiden kaksi viimeistä vokalia ovat yhdet, katoo $h$ vartalosta ja loppu-aspirationi muuttuu, kuten edellisessä nähtiin, s:äksi [imes 'ihme'] - -. (Almberg 1870: 114)

Esimerkissä 31 muutos on ollut todellisuudessa päinvastainen kuin koveta-verbi antaa ymmärtää, sillä aspiraatio on aiemman sananloppuisen $k$ :n heikentymä, ei sen edeltäjä. Tosin $k$ :n alkuperäisyyskin mainitaan jo 189o-luvulla (Reijonen 1893: 13). Sananloppuisen $n: \mathrm{n}, t: \mathrm{n}$ ja $h: \mathrm{n}$ muutokset, jotka esimerkeissä $33-35$ on selitetty aspiraation avulla, ovat kielihistoriallisesti assimilaatiota $(-n)$ tai analogiaa $(-t,-h)$.

Deskriptiivinen murteentutkimus vaihtui fonetiikkaa hyödyntävään äännehistorialliseen tutkimukseen vähitellen, ja ahlqvistilainen traditio alkoi murtua 1880-luvulla (ks. esim. Korhonen 1986: 168; Häkkinen 2008: 148). Cannelinin Ke-

16. Generatiivisesta murteentutkimuksesta ks. Petyt 1980: 171-185. 
min murteen tutkimus (1889) sisältää vanhasta jäsentelystä ja erikoissanastosta huolimatta runsaasti foneettista ja äännehistoriallista tietoa. Sen esipuheessa (mts. 10) on pitkä luettelo lähteitä, joihin kuuluvat muun muassa Eduard Sieversin fonetiikan teos, Jost Wintelerin murretutkimus (molemmat 1876, ks. alaviitettä 1), useita kielioppeja ja sukukielten tutkimuksia sekä Setälän äänneopin luennot. Hyyryläinen (1893) käsittelee murteen muutoksia jo Setälän äännehistoriaan tukeutuen, mutta jäsentely ja termistö noudattelevat suurelta osin aiempia malleja. Äännehistoriallinen näkökulma käy ilmi esimerkiksi siitä, että Hyyryläinen mainitsee konsonanttiluettelossaan aspiraation sijasta laryngaaliklusiilin ja selittää sen joskus kuuluvan murteessa "yhteissuomalaisen loppu- $k: n$ " vastineena (mts. 6, 8). Äänteiden "yhteissuomalaiseen" edustukseen perustuva jäsentely on ensimmäisen kerran lähtökohtana J. H. Wennolan ja Artturi Kanniston äänneopillisissa tutkimuksissa 1897 (Setälän mallista ks. Häkkinen 2008: 148-149). Niistä ovat kadonneet monet aiempien tutkimusten termit, eikä ilmiöitä ole aina nimetty selvästi. Wennola (1897: 17) toteaa pohjoispohjalaisesta yleisgeminaatiosta luvussa Laajuus, että "kaikki konsonantit ääntyvät murteessa pitkänä" tietyissä asemissa. Astevaihtelun esittelyssä Wennola ja Kannisto lähtevät kantasuomen konsonanteista, joita murteessa vastaa tai edustaa tietty äänne tai kato. Termiä astevaihtelu heillä ei ole, vaan se tulee esiin vasta seuraavan vuosikymmenen murretutkimuksissa. Jänneksen (Genetzin) kieliopissa $(1895: 16,18)$ puhutaan vielä "umpinaisten konsonanttien heikkenemisestä" ja "pehmennyssäännöistä", mutta Setälän kieliopissa (1898: 17) on jo otsikko Astevaihtelu ja astevaihtelun määritelmässä ilmaus vahvan ja heikon asteen vaihtelu.

Myöhäiskantasuomen äänteisiin perustuva dispositioperiaate jatkui myöhemmissä äännehistorioissa, joskin niissä pyrittiin esittelemään myös kokonaisia ilmiöitä (esim. Ojansuu 1901: Labialiseeraus, Diftongireduseeraus, Sisäheitto, Loppuheitto). Tässä jäsentelyssä historiallisesti yhteen kuuluvat ilmiöt hajaantuivat moneen eri kohtaan, ja tutkimuksia kritisoitiin kaavamaisuudesta, mekaanisuudesta ja pirstaleisuudesta (esim. Kettunen 1912: 122-123; Rapola 1925: 83). Voi siis sanoa, että jäsentelynsä puolesta ensimmäisten vuosikymmenien murretutkimukset olivat pitemmällä kuin äännehistorialliset analyysit, sillä ilmiöt oli esitetty omina lukuinaan tai ne oli koottu yhteisten otsikoiden alle. Kantasuomen rekonstruktioon perustuva tutkimusote houkutteli alkuvaiheessa myös tekemään liian pitkälle meneviä ja virheellisiä päätelmiä. Kielioppien ja murretutkimusten kuvaus konsonanttien pehmenemisestä eli astevaihtelusta vaihtui Setälän teorioinnissa iältään vanhempaan ja esiintymisehdoiltaan laajempaan käsitykseen kvantiteettivaihtelusta. Kiistelyn kohteeksi nousi myös yleisgeminaatio, joka sekin oli esitetty vanhoissa tutkimuksissa nykyiseen tapaan. (Ks. Korhonen 1986: 129-133; Juusela 2006: 150-156; Häkkinen 2008: 135-141.)

\section{Lopuksi}

Murteentutkimuksen nykytermistön ja metakielen pohja luotiin jo ensimmäisissä suomenkielisissä tutkimuksissa. Deskriptiivisen, vertailevan metodin mukaisissa murreanalyyseissa käytettiin sanastoa, joka on osittain säilynyt nykypäivään asti, ja osa murrepiirteitä nimeävistä erikoistermeistäkin on yhä käytössä. Tieteellinen suomen kieli 
oli tuolloin kuitenkin vasta alkuvaiheissaan, ja kirjakieltä kehitettiin ja normitettiin koko ajan. Vaikka kielentutkimuksen paradigma vaihtui 189o-luvulla, uudet menetelmät eivät täysin uudistaneet murteentutkimuksen metakieltä. Nuorgrammaattisen metodin mukaisissa tutkimuksissa säilyi edelleen kielioppimainen esitystapa, ja metakielinen ilmaisu oli jopa niukempaa ja kaavamaisempaa kuin aiemmin. Uusia termejä tuli vähitellen entisten tilalle, mutta niiden valintaa ei juuri pohdittu tai selitetty eikä termeihin kiinnitetty huomiota myöskään arvosteluissa. Murrepiirteisiin liittyvien termien vakiintuminen äännehistorioihin olisikin kokonaan oma tutkimustehtävänsä, sillä edellä olen voinut tuoda esiin vain joitakin esimerkkejä vertailevan kauden jälkeisistä muutoksista.

Tieteellisen kielen hiominen sananvalinnoiltaan mahdollisimman neutraaliksi, objektiiviseksi rekisteriksi on vienyt aikaa. Minkä tahansa 180o-luvun asiatekstin kielenkäyttö saattaa vaikuttaa nykyään kansanomaiselta, tunnevaltaiselta tai ekspressiiviseltä, sillä sanojen merkitykset ja tyylisävyt sekä myös tyyli-ihanteet ovat muuttuneet. Silti jo ensimmäisten murteentutkijoiden suhde kohteeseensa oli asiallinen ja neutraali. Silloinkin kun murrepiirteitä esiteltiin murteen personoinnin avulla, siis toimijuudesta käsin, päähuomio oli äänteissä ja varianteissa. Myöskään "oman kielen" ihannointi ei näy murretutkimusten metakielessä, kuten voisi odottaa 1800-luvun kansallisideologista taustaa vasten. Erikoiskielen käytössä murteentutkimus oli kansainvälisemmällä pohjalla kuin mihin aikakauden purismi olisi voinut johtaa, sillä sen termistö sisälsi kielioppisanaston lisäksi muitakin vierassanoja. Niiden vastineiksi luotiin eri tavoin myös omaperäisiä uudissanoja, ja käsitteet, joille ei ollut yhteistä taustaa tai mallia muissa kielissä, ilmaistiin suomeksi. Kaikille ilmiöille ei kuitenkaan syntynyt termimäisiä nimityksiä, ja varsinkin vokaaliston piirteitä kuvattiin usein verbeillä, joita voi pitää niin sanottuina pragmaattisina käyttötermeinä.

Vanhimpien murretutkimusten metakieli paljastaa sen, että tutkijat olivat hyvin selvillä suomen kielen rakenteesta. Kielioppien ja sukukielten avulla he pystyivät tekemään päätelmiä myös murrevarianttien ikäsuhteista, siis murteen todellisesta muuttumisesta. Kaikkia piirteitä ei kyetty metodien puutteessa selittämään samalla tavalla kuin fonetiikan ja murremaantieteen tukemissa äännehistorioissa on tehty. Tutkimukset sisältävät silti huomionarvoisia analyyseja monista ilmiöistä, jopa sellaisista, jotka äänneryhmiin perustuvassa jäsentelyssä jäivät myöhemmin syrjään. On myös otettava huomioon, että murteista ei ollut olemassa minkäänlaista yleisesitystä eikä selkeitä maantieteellisiä ryhmittelyjä. Eri murteiden tutkijoilla oli analysoitavanaan erilainen kokoelma kirjakielestä poikkeavia ilmiöitä, ja jokainen joutui hahmottamaan ja jäsentämään havaitsemansa piirteet omalla tavallaan, ilman tarkkaa käsitystä suomen murteiden kokonaisuudesta.

\section{Lähteet}

\section{Aineistolähteet}

Almberg, Erkкi 1870: Isojoen kielimurteesta. Suomi II:8.

Aminoff, T[orsten] G. 1871: Tutkimus Etelä-Pohjanmaan kielimurteesta. Suomi II:9.

— 1876: Tietoja Wermlannin Suomalaisista. Suomi II:11. 
Aspelin, J. R. 1870: Tavoista ja kielimurteesta Ylivetelin pitäjässä. Suomi II:8.

Brax, Peкka 189o [1889]: Pohjois-Savon kielimurteesta. Ä̈̈nne- ja muoto-opillinen tutkimus. Suomi III:3.

Cannelin, KnUt 1889 [1888]: Tutkimus Kemin kielenmurteesta. Suomi III:2.

Chydenius, E. J. 1886: Laihian murteesta. - Virittäjä II s. 98-122.

Grotenfelt, Ossian 1878: Pohjois-Hämeen kielimurteesta. Suomi II:12.

Hahnsson, J. A. 1866-1872: Muoto-opillinen selitys Eurajoen, Lapin, Rauman, Pyhänmaan, Laitilan ja Uudenkirkon pitäjien kielestä. Suomi II:6-10.

Hannikainen, O. 1886: Kielenmurteesta Parikkalan pitäjässä. Suomi II:19.

Hyyryläinen, Otto 1893: Tutkimus Hirvensalmen kielestä. Suomi III:7.

Jännes, ARVi 1890 [1889]: Kielellisiä muistoonpanoja Kaakkois-Karjalasta. Suomi III:3.

Koskinen, YRJÖ 1852 [1851]: Kertomus Hämeenkyrön pitäjästä. Suomi 1851.

Könönen, T. 1888: Äänne- ja muoto-opillisia tutkimuksia Pälkijärven kielimurteesta. Kuopio: Kuopion Isänmaallinen Seura.

Leino, G. E. 1890 [1889]: Lopen pitäjän kielimurteesta. Tutkimuskoe. Suomi III:3.

Lindfors, A. E. 1893 [1892]: Tutkimus Heinolan murteesta. Suomi III:6.

Lönnвонм, O. A. F. 1879: Jääsken, Kirvun ja osittain Rautjärven ja Ruokolahden pitäjien kielimurteesta. Suomi II:13.

Reijonen, ERKKi 1893 [1892]: Nurmeksen murteesta. Ä̈̈ne- ja muoto-opillinen tutkimus-koe. Suomi III:6.

Salonius, Pa avo 1872: Kielimurteista Kiskon, Karjalohjan, Lohjan, Wihdin ja Nurmijärven pitäjissä. Suomi II:10.

— 1881: Tutkimus kielimurteesta Tornion seuduilla. Suomi II:14.

Suomi. Kirjoituksia isänmaallisista aineista. Helsinki: Suomalaisen Kirjallisuuden Seura.

Toivonen, J. G. 1889 [1888]: Tutkimus Halikon kielestä. Kielioppi ja kielennäytteitä. Suomi III:2.

Warelius, Antero 1855 [1853]: Kertomus Tyrvään pitäjästä 1853. Suomi 1854. Fjortonde årgången.

Westerlund, SAKari A. 1883: Muistoonpanoja Lammin-Kosken kappelin puheenparresta. Virittäjä I s. 189-215.

Kirjallisuus

Ahlqvist, AUgust 1877: Suomen kielen rakennus. Vertaavia kieliopillisia tutkimuksia I. SWK 7.

Bussmann, Hadumod 1990: Lexikon der Sprachwissenschaft. Zweite, völlig neu bearbeitete Auflage. Stuttgart: Alfred Kröner Verlag.

EurÉn, G. E. 1852: Suomalainen Kielioppi Suomalaisille. SWK 5.

FP = Iivonen, Antti - Horppila, Mari - Heikkonen, Miika - Rissanen, Olli: Fonetiikan perussanasto. Verkkotoimitus. Esa-Pekka Keskitalo. Helsingin yliopisto, Fonetiikan laitos. https://helda.helsinki.fi/bistream/handle/10224/3513/index.htm (25.4.2016).

Genetz, Arvid 1881: Suomen kielen äänne- ja muoto-oppi ynnä runous-oppi. Oppikouluja varten. SWK 8. Ks. myös Jännes, Arvi.

HaARALA, Risto 1981: Sanastotyön opas. Kotimaisten kielten tutkimuskeskuksen julkaisuja 16. Helsinki: Kotimaisten kielten tutkimuskeskus.

HAKUlinen, LAURI 1979: Suomen kielen rakenne ja kehitys. Neljäs, korjattu ja lisätty painos. Helsinki: Otava. 
Huumo, Katja 2005: "Perkeleen kieli". Suomen kieli ja poliittisesti korrekti tiede 180o-luvulla. Bidrag till kännedom av Finlands natur och folk 166. Helsinki: Suomen Tiedeseura.

Häk kinen, Kais A 1994: Agricolasta nykykieleen. Suomen kirjakielen historia. Porvoo: WSOY.

2000: Suomen kirjakielen sijajärjestelmän vakiintuminen 180o-luvulla. - Matti Punttila, Raimo Jussila \& Helena Suni (toim.), Pipliakielestä kirjakieleksi s. 171-201. Kotimaisten kielten tutkimuskeskuksen julkaisuja 105. Helsinki: Kotimaisten kielten tutkimuskeskus.

2008: Suomen kielen historia 2. Suomen kielen tutkimuksen historia. Turun yliopiston suomalaisen ja yleisen kielitieteen laitoksen julkaisuja 78. Turku: Turun yliopisto.

ItKonen, ERKKi 1966: Kieli ja sen tutkimus. Helsinki: WSOY.

Jussila, RAimo 1998: Vanhat sanat. Vanhan kirjasuomen ensiesiintymiä. Helsinki: Suomalaisen Kirjallisuuden Seura \& Kotimaisten kielten tutkimuskeskus.

Ju usela, KaIsu 2006: Sata vuotta Virittäjää. Kotikielen Seuran aikakauslehden vaiheita vuosilta 1897-1996. SKST 1031.

Jännes, Arvi 1895: Suomen kielioppi. Alkeis-, muoto- ja runo-oppi. Oppikouluja varten. Neljäs painos. SWK 10. Ks. myös Genetz, Arvid.

JÄrvinen, NeStor 1854 [1853]: Om några dialekt-egenheter i Satakunta. Suomi 1853. Trettonde årgången.

KALliokosKi, JyRKI 1995: Kieli, tunteet ja ideologia uutisteksteissä. Näkymiä tekstilajin historiaan ja nykyisyyteen. - Jyrki Kalliokoski (toim.), Teksti ja ideologia. Kirjoituksia kielestä ja vallasta julkisessa kielenkäytössä s. 37-97. Kieli 9. Helsinki: Helsingin yliopiston suomen kielen laitos.

Kannisto, Artturi 1897: Ä̈̈nneopillinen tutkimus Urjalan, Kylmäkosken ja Akaan murteesta. Suomi III:14.

Karihalme, Oili 1996: Muotoilun teoriasanaston termistyminen. Acta Wasaensis No 51. Kielitiede 10. Vaasa: Vaasan yliopisto.

Kelomäкi, TAPANi 2009: Nuorgrammaattisuuden myytti suomen kielen tutkimuksessa. Helsinki: Helsingin yliopiston suomen kielen ja kotimaisen kirjallisuuden laitos.

Kettunen, LAuri 1912: Äännehistoriallinen tutkimus Tornion murteesta [arvostelu teoksesta Martti Airila 1912: Ä̈̈nnehistoriallinen tutkimus Tornion murteesta]. - Virittäjä 16 s. 121-128.

1940: Suomen murteet III A. Murrekartasto. SKST 188.

Koranteri, H. K. 1845: Suomalajnen Kieli-Oppi, Kowlujen tarpe’eksi. SWK 4.

Korhonen, Miкко 1986: Finno-Ugrian language studies in Finland 1828-1918. Helsinki: Societas Scientiarum Fennica.

KS = Kielitoimiston sanakirja. Verkkoversio. Helsinki: Kotimaisten kielten keskus. URN:NBN:fi:kotus-201433. www.kielitoimistonsanakirja.fi (25.4.2017).

LAINE, PÄIvi 2007: Suomi tiellä sivistyskieleksi. Suomenkielisen maantieteen sanaston kehittyminen ja kehittäminen 180o-luvulla. Turun yliopiston suomalaisen ja yleisen kielitieteen laitoksen julkaisuja 77. Turku: Turun yliopisto.

Laitinen, Lea 2004: Kieltosana ja kieletär. Yhden kielikiistan kulku ja ideologiat. - Katja Huumo, Lea Laitinen \& Outi Paloposki (toim.), Yhteistä kieltä tekemässä. Näkökulmia suomen kirjakielen kehitykseen 1800-luvulla s. 177-222. SKST 979.

LÖNNR. = LÖNNROT, ELIAS 1866-1880: Suomalais-Ruotsalainen sanakirja I-II. Kolmas, manual-menetelmällä jäljennetty painos. Helsinki: WSOY 1958.

MielikëInen, Aila 1994: Etelä-Savon murteiden äännehistoria II. Vokaalit. SKST 599.

— 2004: Liudennus murretutkimuksissa ja savolaismurteisessa kirjallisuudessa. - Virittäjä 108 s. 508-530. 
2005: Matkimuksista määritelmiin. Miten murteista puhutaan. - Sananjalka 47 s. 98-118.

Mielikäinen, Aila - Palander, Marjatta 2014: Miten murteista puhutaan? Kansanlingvistinen tutkimus metakielestä. Suomi 203. Helsinki: Suomalaisen Kirjallisuuden Seura.

Miknola, Kati - Laitinen, Lea 2013: Mielen ja kielen muutoksia. - Lea Laitinen \& Kati Mikkola (toim.), Kynällä kyntäjät. Kansan kirjallistuminen 180o-luvun Suomessa s. 413-463. SKST 1370.

NinnivaA RA, Mart ti 1931: Kielen tutkimus ja viljely. - Suomalaisen Kirjallisuuden Seura 1831-1931. Suomi V:12.

NORDlund, TARU 2004: Arat taimet ja ankaran puutarhurit. 1800-luvun lopun kielikeskustelun metaforat ja kieli-ideologiat. - Katja Huumo, Lea Laitinen \& Outi Paloposki (toim.), Yhteistä kieltä tekemässä. Näkökulmia suomen kirjakielen kehitykseen 18oo-luvulla s. 286-322. SKST 979.

NS = Nykysuomen sanakirja I-III. Lyhentämätön kansanpainos. Kolmas painos. Porvoo: WSOY 1970.

Nyman, Mart ti 1905: [Arvostelu teoksesta] Heikki Ojansuu 1901, 1903: Suomen lounaismurteiden ä̈nnehistoria. - Virittäjä 9 s. 78-82.

OjansuU, HeI K K 1901: Suomen lounaismurteiden äännehistoria I. Vokaalioppi. Suomi III:19.

PAlAnder, MarJatTa 1987: Suomen itämurteiden erikoisgeminaatio. SKST 455.

Paunonen, Heik i 1976: Kotikielen Seura 1876-1976. - Virittäjä 8o s. 310-432.

Ретут, K. M. 1980: The study of dialect. An introduction to dialectology. London: Andre Deutsch.

PitKänen, KAARINA 2008: Suomi kasvitieteen kieleksi. Elias Lönnrot termistön kehittäjänä. SKST 1164.

Pulkininen, PaAvo 1996: Uudenlaista "liudentumista". - Kielikello 1/1996 s. 31-32.

RAPOlA, MARTti 1925: Uusi suomalainen murretutkimus. [Arvostelu teoksesta Niilo Ikola 1925: Ala-Satakunnan murteen äännehistoria 1.] - Virittäjä 29 s. 82-86.

— 1960: Sanojemme ensiesiintymiä Agricolasta Yrjö Koskiseen. Tietolipas 22. Helsinki: Suomalaisen Kirjallisuuden Seura.

— 1961: Johdatus suomen murteisiin. Toinen, uudistettu painos. Tietolipas 4. Helsinki: Suomalaisen Kirjallisuuden Seura.

1965 [1933]: Suomen kirjakielen historia pääpiirteittäin I. Muuttamaton jäljennöspainos. SKST 197.

1966: Suomen kielen ä̈̈nnehistorian luennot. SKST 283.

Ravila, PaAvo 1966: Johdatus kielihistoriaan. 3., uusittu painos. Tietolipas 3. Helsinki: Suomalaisen Kirjallisuuden Seura.

SEtäLÄ, E. N. 1898: Suomen kielioppi. Ä̈̈nne- ja sanaoppi. Oppikoulua ja omin päin opiskelua varten. SWK 10 .

SKS 1867-68 = Suomalaisen Kirjallisuuden Seuran Keskustelemukset v. 1867-68. Suomi II:8.

SKST = Suomalaisen Kirjallisuuden Seuran Toimituksia. Helsinki: Suomalaisen Kirjallisuuden Seura.

SMS = Suomen murteiden sanakirja 3-4, 6. Helsinki: Kotimaisten kielten tutkimuskeskus \& Valtion painatuskeskus, Edita 1992, 1994, 1999.

SMS 2016 = Suomen murteiden sanakirjan tarkistamaton käsikirjoitus. Helsinki: Kotimaisten kielten keskus.

Suomi. Kirjoituksia isänmaallisista aineista. Helsinki: Suomalaisen Kirjallisuuden Seura.

SWK = WiıK, KAlevi (toim.) 1987: SWK eli Suomen Wanhat Kieliopit. Niteet 6-10. Turku: Turun Yliopisto, Fonetiikka. 
Tarkiainen, V. 1904 [1903]: Ä̈nnehistoriallinen tutkimus Juvan murteesta. Suomi IV:2.

— 1913: Muutama sana suomenkielen lausumisesta. - Virittäjä 17 s. 89-94.

Tieteen termipankki. www.tieteentermipankki.fi (31.10.2016).

VKS = Vanhan kirjasuomen sanakirja 2 . J-K. Kotimaisten kielten tutkimuskeskuksen julkaisuja

33. Helsinki: Kotimaisten kielten tutkimuskeskus \& Painatuskeskus 1994.

WARELIUS, ANDERS 1848 [1847]: Bidrag till Finlands kännedom i ethnographiskt hänseende. Suomi 1847. Sjunde årgången.

Wennola, J. H. 1897 [1896]: Ä̈nneopillisia havainnoita Pohjois-Pohjanmaan rantamurteesta. Suomi III:13.

Wichmann, YrJö 1893 [1892]: Muutamia äänneopillisia havainnoita Lestijoen murteesta. Suomi III:6.

\section{The metalanguage of the first Finnish-language studies in dialectology}

The roots of Finnish dialectology go back to a point in the 19th century when scholarly Finnish did not yet exist. Little had been written on linguistics in Finnish, and grammars were often in languages other than Finnish. The terminology gleaned from grammars written in Finnish for the treatment of dialectal phonology was insufficient, i.e., scholars writing in Finnish lacked suitable metalinguistic models. The present article examines the terminology used to describe typical features of a variety of dialects during the first decades of dialectology. The primary corpus of data consists of studies, published from 1860 until the 1890 os and which represent a comparative descriptive approach. The paradigmatic change from descriptive to historical dialectology in Europe (during the 1870s) did not reach Finland until two decades later. Prior to this, dialects were compared to the literary language presented in grammars. While scholars were well acquainted with the structure of the Finnish language, they could also explain, to some degree, the background and birth of dialectal variations. For this reason, analyses are not as synchronic as the method used might suggest.

The article also studies metalanguage in the linguistic context of the specific point of time in question. One of the aims of the language reforms of the 19th century was a Finnish-language-based collection of neologisms, an attempt to create Finnish equivalents for scholarly terms. Dialectological terminology employs both foreign and Finnish vocabulary, and some of these terms persist to this day. Familiar words were given a new meaning in a linguistic context, and new derivatives were created. The choice of 
words was sometimes popular in tone, occasionally reminiscent of a modern folk linguistic metalanguage. It is, nevertheless, to be noted, that the stylistics of words has changed, and that the stylistic values of expressive and affective words could have had a more neutral shade during the 19th century.

\section{Ensimmäisten suomenkielisten murretutkimusten metakieli}

Suomalaisen murteentutkimuksen alku sijoittuu 180o-luvulla ajankohtaan, jolloin tieteellistä suomen kieltä ei vielä ollut olemassa. Kielestäkin oli kirjoitettu suomeksi vähän, ja kieliopit olivat suurimmaksi osaksi muunkielisiä. Suomenkielisistä kieliopeista saatu terminologia ei riittänyt murteiden äänneopin käsittelyyn, eli suomeksi kirjoittavilta tutkijoilta puuttuivat sopivat metakielen mallit. Tässä artikkelissa tarkastellaan, miten eri murteiden tyypillisiä piirteitä nimettiin ja kuvailtiin murteentutkimuksen ensimmäisinä vuosikymmeninä. Aineistona ovat 1860-189o-luvuilla julkaistut tutkimukset, jotka edustavat vertailevaa, deskriptiivistä tutkimussuuntaa. Euroopassa 1870-luvulla tapahtunut paradigman muutos deskriptiivisestä historioivaan tutkimukseen (nuorgrammaattinen tutkimussuunta) saavutti suomalaisen murteentutkimuksen vasta $1890-l u v u l l a$. Sitä ennen murteita verrattiin kieliopeissa esitettyyn kirjakieleen. Tutkijat tunsivat hyvin suomen kielen rakenteen, mutta he pystyivät jossain määrin selittämään myös murrevarianttien taustoja ja syntyä. Analyysit eivät siten ole niin synkronisia kuin käytetyn metodin perusteella voisi olettaa.

Artikkelissa tarkastellaan metakieltä myös tutkimusajankohdan kielellisessä kontekstissa. 180o-luvun kielenuudistuksessa oli yhtenä tavoitteena uudissanaston omaperäisyys, ja tieteellisille termeillekin pyrittiin luomaan suomenkieliset vastineet. Murretutkimusten terminologia sisältää sekä vierasperäistä että omaa sanastoa, ja osa siitä on säilynyt dialektologiassa nykypäivään asti. Ennestään tutuille sanoille annettiin kielitieteellisessä kontekstissa uusi merkitys, ja lisäksi luotiin tarpeen mukaan uusia johdoksia. Sananvalinnat saattavat joskus kuulostaa kansanomaisilta ja muistuttaa jopa nykyistä kansanlingvististä metakieltä. On kuitenkin otettava huomioon, että sanojen tyylisävyt ovat muuttuneet ja että nykykielen ekspressiivisillä ja affektiivisilla sanoilla on voinut olla 180o-luvulla neutraalimpi merkitys.

Kirjoittajan yhteystiedot (address):

etunimi.sukunimi@jyu.fi 